\begin{tabular}{|c|l|}
\hline Title & $\begin{array}{l}\text { Glutamate Receptor } \delta \text { 2 Is Essential for Input Pathway-Dependent Regulation of Synaptic A MPA R Contents in } \\
\text { Cerebellar Purkinje Cells }\end{array}$ \\
\hline Author(s) & $\begin{array}{l}\text { Yamasaki, Miwako; Miyazaki, Taisuke; A zechi, Hirotsugu; A be, Manabu; Natsume, Rie; Hagiwara, Teruki; A iba, } \\
\text { A tsu; Mishina, Masay oshi; Sakimura, Kenji; W atanabe, Masahiko }\end{array}$ \\
\hline Citation & $\begin{array}{l}\text { The Journal of Neuroscience, 31(9), 3362-3374 } \\
\text { https://doi.org/10.1523/NNEUROSCI.5601-10.2011 }\end{array}$ \\
\hline Issue Date & 2011-03-02 \\
\hline Doc URL & http:/hdl.handle.net/2115/47052 \\
\hline Type & article \\
\hline File Information & JoN31-9_3362-3374.pdf \\
\hline
\end{tabular}

Instructions for use 


\title{
Glutamate Receptor $\delta 2$ Is Essential for Input Pathway-Dependent Regulation of Synaptic AMPAR Contents in Cerebellar Purkinje Cells
}

\author{
Miwako Yamasaki, ${ }^{1}$ Taisuke Miyazaki, ${ }^{1}$ Hirotsugu Azechi, ${ }^{2}$ Manabu Abe, ${ }^{2}$ Rie Natsume, ${ }^{2}$ Teruki Hagiwara, ${ }^{2}$ Atsu Aiba, ${ }^{4}$ \\ Masayoshi Mishina, ${ }^{3}$ Kenji Sakimura, ${ }^{2,5}$ and Masahiko Watanabe ${ }^{1,5}$ \\ ${ }^{1}$ Department of Anatomy, Hokkaido University Graduate School of Medicine, Sapporo 060-8638, Japan, 2Department of Cellular Neurobiology, Brain \\ Research Institute, Niigata University, Niigata 951-8585, Japan, ${ }^{3}$ Department of Molecular Neurobiology and Pharmacology, Graduate School of Medicine \\ and ${ }^{4}$ Laboratory of Animal Resources, Center for Disease Biology and Integrative Medicine, Faculty of Medicine, The University of Tokyo, Tokyo 113-0033, \\ Japan, and ${ }^{5} J a p a n$ Science and Technology Agency, Core Research for Evolutional Science and Technology (CREST), Sanbocho, Chiyada-ku, \\ Tokyo 102-0075, Japan
}

The number of synaptic AMPA receptors (AMPARs) is the major determinant of synaptic strength and is differently regulated in input pathway-dependent and target cell type-dependent manners. In cerebellar Purkinje cells (PCs), the density of synaptic AMPARs is approximately five times lower at parallel fiber (PF) synapses than at climbing fiber (CF) synapses. However, molecular mechanisms underlying this biased synaptic distribution remain unclear. As a candidate molecule, we focused on glutamate receptor $\delta 2$ (GluR $\delta 2$ or GluD2), which is known to be efficiently trafficked to and selectively expressed at PF synapses in PCs. We applied postembedding immunogold electron microscopy to GluR $\delta 2$ knock-out (KO) and control mice, and measured labeling density for GluA1-4 at three excitatory synapses in the cerebellar molecular layer. In both control and GluR $\delta 2-K 0$ mice, GluA1-3 were localized at PF and CF synapses in PCs, while GluA2-4 were at PF synapses in interneurons. In control mice, labeling density for each of GluA1-3 was four to six times lower at PF-PC synapses than at CF-PC synapses. In GluR $\delta 2-K 0$ mice, however, their labeling density displayed a three- to fivefold increase at PF synapses, but not at CF synapses, thus effectively eliminating input pathway-dependent disparity between the two PC synapses. Furthermore, we found an unexpected twofold increase in labeling density for GluA2 and GluA3, but not GluA4, at PF-interneuron synapses, where we identified low but significant expression of GluR $\delta 2$. These results suggest that GluR $\delta 2$ is involved in a common mechanism that restricts the number of synaptic AMPARs at PF synapses in PCs and molecular layer interneurons.

\section{Introduction}

The AMPA-type glutamate receptor (AMPAR) mediates most fast excitatory transmission in the CNS. AMPARs are tetrameric channels assembled from GluA1-4 subunits (GluR1-4 or GluR-A to -D) (Keinänen et al., 1990; Hollmann and Heinemann, 1994). In particular, inclusion of GluA2 in AMPARs determines channel kinetics, rectification, and $\mathrm{Ca}^{2+}$ permeability (Bochet et al., 1994; Jonas et al., 1994). Subunit composition is also important for AMPAR trafficking (Shi et al., 2001; Malinow and Malenka, 2002; Bredt and Nicoll, 2003; Shepherd and Huganir, 2007). GluA2-containing receptors constitutively cycle into and out of synapses, whereas GluA1containing receptors undergo activity-dependent insertion and, otherwise, are excluded from synapses. At synapses, the number of AMPARs critically depends on specific interaction with transmem-

Received 0ct. 26, 2010; revised Dec. 16, 2010; accepted Jan. 5, 2011.

This study was supported through Special Coordination Funds for Promoting Science and Technology, Grants-inAid for Scientific Research (S; 19100005 to M.W.), and Grants-in-Aid for Scientific Research on Priority Area (17023001 to M.W.) provided by the Ministry of Education, Culture, Sports, Science and Technology of Japan.

Correspondence should be addressed to Masahiko Watanabe, Department of Anatomy, Hokkaido University Graduate School of Medicine, Sapporo 060-8638, Japan. E-mail: watamasa@med.hokudai.ac.jp.

DOI:10.1523/JNEUROSCI.5601-10.2011

Copyright $\odot 2011$ the authors $\quad 0270-6474 / 11 / 313362-13 \$ 15.00 / 0$ brane AMPAR regulatory proteins (TARPs) and "slot" proteins, such as PSD-95 (Schnell et al., 2002; Stein et al., 2003; Ehrlich and Malinow, 2004; Bats et al., 2007).

Most neurons in the CNS receive glutamatergic inputs from several sources, and AMPAR contents at given synapses are differently regulated. For example, in hippocampal CA3 pyramidal cells, mossy fiber synapses have approximately four times more AMPARs than associational/commissural fiber (A/C) synapses, suggesting input pathway-dependent regulation (Nusser et al., 1998; Masugi-Tokita et al., 2007). Likewise, in cerebellar Purkinje cells (PCs), climbing fiber (CF) synapses have five times more AMPARs than parallel fiber (PF) synapses (Masugi-Tokita et al., 2007). On the other hand, A/C synapses on interneurons have four times more AMPARs than those on pyramidal cells in the hippocampal CA3, showing target cell type-dependent regulation (Nusser et al., 1998). However, the mechanisms underlying the biased synaptic distribution of AMPARs remain unclear.

Glutamate receptor GluR $\delta 2$ (GluD2) is selectively expressed at postsynaptic sites of PF synapses, but not CF synapses, in PCs (Takayama et al., 1996; Landsend et al., 1997). At PF-PC synapses, GluR $\delta 2$ plays a key role in the formation and maintenance of PF-PC synapses (Kashiwabuchi et al., 1995; Kurihara et al., 
1997; Lalouette et al., 2001; Takeuchi et al., 2005; Matsuda et al., 2010; Uemura et al., 2010). Furthermore, GluR $\delta 2$ regulates endocytosis of AMPARs (Hirai et al., 2003) and mediates long-term depression (LTD) at PF-PC synapses (Kashiwabuchi et al., 1995). These characteristics led us to hypothesize that GluR $\delta 2$ could also be involved in the input pathway-dependent biased distribution of AMPARs at PC synapses. To explore this possibility, we applied postembedding immunogold electron microscopy to GluR $\delta 2$ knock-out (KO) and control mice, and measured labeling density for GluA1-4 at three excitatory synapses in the cerebellar molecular layer. In GluR $\delta 2-K O$ mice, GluA1-3 exhibited a marked (three- to fivefold) increase at PF-PC, but not CF-PC, synapses. Consequently, input pathway-dependent distribution of synaptic AMPARs in control PCs was almost eliminated in GluR $\delta 2-K O$ PCs. Unexpectedly, a modest (twofold) increase of GluA2 and GluA3, but not GluA4, was also found at PF synapses in molecular layer interneurons (basket/stellate cells), where we identified low but significant expression of GluR $\delta 2$. Therefore, GluR $\delta 2$ is involved in a common mechanism that suppresses synaptic expression of particular GluA subunits at PF synapses in PCs and basket/stellate cells.

\section{Materials and Methods}

Animals. All experiments were performed according to the guidelines laid down by the animal welfare committees of Hokkaido University and Niigata University. The Grid2-Cre mutant mouse line was produced by homologous recombination of the GluR $\delta 2$ gene (Grid2) with the Cre recombinase gene inserted into the translational initiation site of the GluR $\delta 2$ gene (Grid2) and by electroporation into the C57BL/6N ES cell line RENKA (Mishina and Sakimura, 2007) (supplemental Fig. S1, available at www.jneurosci.org as supplemental material). We constructed a targeting vector whose Cre gene had been inserted into the translation initiation site of the Grid2 in frame. The 1.8-kb DNA fragment, which carried the polyA signal sequence and Pgk-1 promoter-driven neomycin phosphotransferase gene (neo) flanked by two flippase recognition target (frt) sites (Takeuchi et al., 2002), was inserted into the downstream of Cre. The targeting vector ptvd2Cre contained the translational initiation site of the GluR $\delta 2$ gene inserted by Cre sequences, $4.9 \mathrm{~kb}$ upstream and $6.8 \mathrm{~kb}$ downstream genomic sequences, and $4.3 \mathrm{~kb}$ pMC1DTpA (supplemental Fig. S1 A, available at www.jneurosci.org as supplemental material) (Kitayama et al., 2001). Heterozygous mutant pairs $\left(\right.$ Grid2 $^{\mathrm{Cre} /+}$ ) were mated to obtain the homozygous male mutant mice ( $\mathrm{Grid2} 2^{\mathrm{Cre} / \mathrm{Cre}}$ ) to be used as GluR $\delta 2$ knock-out (GluR $\delta 2-\mathrm{KO}$ ) mice and to identify Cre-expressing cell types. Cre-expressing cells were further tested using a reporter mouse line (Grid2 ${ }^{\mathrm{Cre} /+}$; CAG-CAT-Z11/+), which was produced by intercrossing the Grid2-Cre line with the Cre-inducible lac $Z$ reporter mouse line (CAG-CAT-Z11) (Araki et al., 1995). Selective Cre expression in the cerebellum of the reporter male mice was tested by $\beta$-galactosidase assay (supplemental Fig. $S 8 A-L$, available at www. jneurosci.org as supplemental material). C57BL/6 male mice were used as control mice. For specificity control for immunohistochemistry, we used null-KO male mice for each of GluA1-4 subunits, which will be reported elsewhere (H. Azechi, M. Abe, M. Watanabe, and K. Sakimura, unpublished observations).

Sections. Under deep pentobarbital anesthesia $(100 \mathrm{mg} / \mathrm{kg}$ body weight, i.p.), brains for in situ hybridization were freshly obtained and immediately frozen in powdered dry ice. Fresh frozen sections $(20 \mu \mathrm{m})$ were cut on a cryostat (CM1900; Leica Microsystems), and mounted on silane-coated glass slides. For immunohistochemistry, mice under deep pentobarbital anesthesia were fixed transcardially with $4 \%$ paraformaldehyde in $0.1 \mathrm{~m}$ sodium phosphate buffer ( $\mathrm{pH} 7.2, \mathrm{~PB})$. Free-floating microslicer sections (50 $\mu \mathrm{m}$ in thickness; VT1000S, Leica Microsystems) were prepared for multiple immunofluorescence labeling and $\beta$-galactosidase assay (Tsujita et al., 1999). Paraffin sections ( $4 \mu \mathrm{m}$; SM1000R; Leica Microsystems) mounted on silane-coated glass slides were also used to compare immunohistochemical intensity for AMPAR subunits and other synaptic molecules. For postembedding immunogold electron micros- copy, microslicer sections ( $400 \mu \mathrm{m}$ ) were cryoprotected with $30 \%$ glycerol in $\mathrm{PB}$, and frozen rapidly with liquid propane in the EM CPC unit (Leica Microsystems). Frozen sections were immersed in $0.5 \%$ uranyl acetate in methanol at $-90^{\circ} \mathrm{C}$ in the AFS freeze-substitution unit (Leica Microsystems), infiltrated at $-45^{\circ} \mathrm{C}$ with Lowicryl HM-20 resin (Chemische Werke Lowi), and polymerized with ultraviolet light. For conventional electron microscopy, mice were perfused transcardially with $2 \%$ paraformaldehyde and $2 \%$ glutaraldehyde in $0.1 \mathrm{~m}$ sodium cacodylate buffer, $\mathrm{pH}$ 7.2. The straight portion of lobules $4 / 5$ was excised, postfixed with $1 \%$ osmium tetroxide for $15 \mathrm{~min}$, stained in block with $2 \%$ uranyl acetate for $30 \mathrm{~min}$, dehydrated, and embedded in Epon 812. Ultrathin sections were made using an Ultracut ultramicrotome (Leica Microsystems).

In situ hybridization. Mouse cDNA fragments of GluA1 (nucleotides 344-1183 bp; GenBank accession number, NM_001113325), GluA2 (408-1247, NM_001083806), GluA3 (262-1101, NM_016886), GluA4

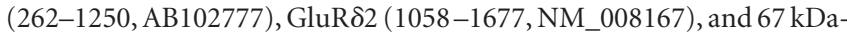
glutamic acid decarboxylase (GAD67; 1036-2015; NM_008077) were subcloned into the pBluescript II plasmid vector. Digoxigenin (DIG)- or fluorescein-labeled cRNA probes were prepared for simultaneous detection of multiple mRNAs by fluorescent in situ hybridization (Yamasaki et al., 2010). In brief, fresh frozen sections were hybridized with a mixture of DIG- or fluorescein-labeled cRNA probes diluted to 1:1000 with hybridization buffer. After stringent posthybridization wash, DIG and fluorescein were detected by the two-step method as follows: the first detection with peroxidase-conjugated anti-fluorescein antibody (Roche Diagnostics, 1:500, 1 h) and the FITC-TSA plus amplification kit (PerkinElmer), and the second detection with peroxidase-conjugated anti-DIG antibody (Roche Diagnostics, 1:500, $1 \mathrm{~h}$ ) and the Cy3-TSA plus amplification kit (PerkinElmer). Residual activities of peroxidase introduced in the first detection were inactivated by incubation of sections with $1.0 \% \mathrm{H}_{2} \mathrm{O}_{2}$ for $30 \mathrm{~min}$. TOTO3 (Invitrogen) was used for fluorescent nuclear counterstaining.

Immunohistochemistry. We used the following primary antibodies: mouse monoclonal anti-Cre recombinase (Millipore Bioscience Research Reagents, MAB3120), goat anti-calbindin (Miura et al., 2006), rabbit anti-GluA1, GluA2, and GluA3 (Yamazaki et al., 2010), guinea-pig anti-GluA4 (Nagy et al., 2004), rabbit anti-GluR $\delta 2$ (Takeuchi et al., 2005), anti-metabotropic glutamate receptor 1 (mGluR1) (Tanaka et al., 2000), rabbit anti-parvalbumin (Miura et al., 2006), rabbit anti-neurogranin (Miyazaki et al., 2011), rabbit anti-PSD-93 and PSD-95 (Fukaya and Watanabe, 2000), rabbit anti-stargazin (TARP $\gamma 2$ ) (Yamazaki et al., 2010), rabbit anti-type 1 vesicular glutamate transporter (VGluT1) (Miyazaki et al., 2003), and guinea pig anti-VGluT2 (Miyazaki et al., 2003).

All immunohistochemical incubations were done at room temperature. For multiple labeling immunofluorescence, microslicer sections were incubated successively with $10 \%$ normal donkey serum for $20 \mathrm{~min}$, mixture of primary antibodies overnight $(1 \mu \mathrm{g} / \mathrm{ml}$ for each), and mixture of Alexa 488-, Cy3-, or Cy5-labeled species-specific secondary antibodies for $2 \mathrm{~h}$ at a dilution of 1:200 (Invitrogen, Jackson ImmunoResearch). Paraffin sections were first subjected to pepsin pretreatment for antigen exposure, i.e., incubation in $1 \mathrm{mg} / \mathrm{ml}$ pepsin (DAKO) in $0.2 \mathrm{~N} \mathrm{HCl}$ for 10 $\min$ at $37^{\circ} \mathrm{C}$. Sections were incubated successively with $10 \%$ normal donkey serum for $20 \mathrm{~min}$ and primary antibodies to AMPAR subunits, PSD-93, PSD-95, stargazin, and GluR $\delta 2(1 \mu \mathrm{g} / \mathrm{ml})$ overnight. Then, most sections were processed by conventional immunofluorescence using fluorophore-labeled secondary antibodies, as above. Some sections to be shown at low magnifications (see Fig. $1 A-D$ ) were processed by the tyramide signal amplification method; they were incubated with biotinylated secondary antibodies for $2 \mathrm{~h}$, avidin-biotin-peroxidase complex for $1 \mathrm{~h}$, and visualized using the TSA-Cy3 system (PerkinElmer).

In postembedding immunogold electron microscopy, ultrathin sections on nickel grids were etched with saturated sodium-ethanolate solution for $1-5 \mathrm{~s}$ and treated with successive solutions, as follows: blocking solution containing $2 \%$ normal goat serum (Nichirei) in the incubation solution $(0.03 \%$ Triton X-100 in Tris-buffered saline, $\mathrm{pH} 7.4$; TTBS) for $20 \mathrm{~min}$, primary antibodies ( $20 \mu \mathrm{g} / \mathrm{ml}$ for each) diluted with the incubation solution overnight, and colloidal gold-conjugated $(10 \mathrm{~nm})$ antirabbit or anti-guinea pig IgG (1:100, British BioCell International) in the blocking solution for $2 \mathrm{~h}$. After extensive washing in TTBS, grids were 
incubated with $2 \%$ normal rabbit or guinea pig serum for $30 \mathrm{~min}$, and then overnight with VGluT1 - or VGluT2-conjugated colloidal immunogold $(15 \mathrm{~nm})$. Colloidal immunogold was prepared according to the method of Slot and Geuze (1985). Finally, grids were washed in TTBS for $30 \mathrm{~min}$, fixed with $2 \%$ glutaraldehyde in PBS for $15 \mathrm{~min}$ and $1 \%$ OsO4 for $20 \mathrm{~min}$, and stained with $2 \%$ uranyl acetate for $5 \mathrm{~min}$ and Reynold's lead citrate solution for $1 \mathrm{~min}$. Photographs were taken with an H-7100 electron microscope (Hitachi). For quantitative analysis, postsynaptic membrane-associated immunogold particles, being defined as those apart $<35 \mathrm{~nm}$ from the cell membrane, were counted on scanned electron micrographs and analyzed using a MetaMorph software (Molecular Devices). Measurements were made from three control and three GluR $\delta 2-K O$ mice. Collected data were pooled together because there was no significant difference in the labeling density among the three animals examined. Statistical significance of the immunogold density was evaluated by Mann-Whitney $U$ test. Statistical significance of cumulative frequency was assessed by Kolmogorov-Smirnov test.

Electron microscopy for three-dimensional reconstruction. Serial ultrathin sections ( $\sim 90 \mathrm{~nm}$ in thickness) were mounted on formvarsupported copper grids, and stained with $2 \%$ uranyl acetate for $5 \mathrm{~min}$ and Reynold's lead citrate solution for 2 min. For measurements of postsynaptic density (PSD) area at PF-PC synapses and of PSD length and synapse density in interneuron dendrites, sampling fields were randomly chosen from a lower half of the molecular layer, and consecutive electron micrographs were taken at an original magnification of $7000 \times$ using an H-7100 electron microscope (Hitachi). Negative film images of serial sections were scanned, aligned, and three-dimensionally (3D) reconstructed using a personal computer-based Reconstruct software (John Fiala and Kristen M. Harris, Center for Learning and Memory, The University of Texas at Austin, Austin, TX; http://synapses.clm.utexas.edu/tools/ reconstruct/reconstruct.stm). PSD area was estimated as the product of the total measured length of a given PSD appearing in a series of sections and the section thickness $(90 \mathrm{~nm})$. Interneuron dendrites were identified as small-calibered dendritic shafts forming numerous asymmetrical synapses. The PSD with the maximal length is selected and measured using a MetaMorph software (Molecular Devices). Statistical significance in synaptic density and PSD length was evaluated by Mann-Whitney $U$ test.

\section{Results \\ Marked increase of GluA2 and GluA3 and mild increase of GluA1 in GluR $\delta$ 2-KO molecular layer}

To investigate a regulatory role of GluR $\delta 2$ in synaptic expression of AMPARs at PC synapses, we examined the cerebellar molecular layer by immunohistochemistry using subunit-specific GluA antibodies. The specificity of each antibody was verified by characteristic immunolabeling in brains of control mice (Fig. $1 A-D$, upper) and negative labeling in those of corresponding GluA subunit-KO mice (lower). To reliably evaluate genotypic differences, a pair of control (C57BL) and mutant (GluR $\delta 2-\mathrm{KO})$ mouse brains were embedded in single paraffin blocks, mounted on the same glass slides, and subjected to immunohistochemical incubation under the same conditions ( $n=3$ pairs). In both GluR $\delta 2-K O$ and control mice, the molecular layer was immunostained for all four GluA subunits, while the granular layer was for GluA2 and GluA4 (Fig. $1 E-L$ ). In the molecular layer of GluR $\delta 2-K O$ mice, we consistently observed a marked increase in immunoreactivity for GluA2 and GluA3, and a mild increase for GluA1 (Fig. $1 E-J$ ). No such changes were observed for GluA2 in the granular layer (Fig. $1 G, H$ ) or for GluA4 in the granular and molecular layers (Fig. $1 K, L$ ).

The subunit-dependent increase of GluA immunoreactivity in the molecular layer appeared to reflect cell type-specific changes of GluA expression. Distinct cellular expression pattern of four GluA mRNAs has been previously shown by isotopic in situ hybridization and single cell reverse transcriptase-PCR (Keinänen et al., 1990; Pellegrini-Giampietro et al., 1991; Burna- shev et al., 1992; Lambolez et al., 1992). We confirmed these observations and further characterized cellular expression of four GluA mRNAs by double-labeling fluorescent in situ hybridization. The specificity of each antisense probe was confirmed by its characteristic labeling (Fig. $2 A-D$ ) and also by blank labeling with the sense probes (insets). Within the molecular layer, GluA1 mRNA was weakly expressed in GAD67 mRNA-expressing neurons in the PC layer (i.e., PCs), but hardly detected in GAD67 mRNA-expressing neurons in the molecular layer (i.e., basket/ stellate cells) (Fig. 2E). Rather, its prominent signals were detected in Bergmann glia, as GluA1 transcripts were dispersed among PCs (Fig. 2E) and overlapped with glutamate transporter GLAST mRNA (data not shown). By contrast, GluA2 and GluA3 mRNAs were high in PCs and interneurons, whereas they were negative in Bergmann glia (Fig. $2 F, G$ ). GluA4 mRNA was moderately expressed in interneurons and Bergmann glia (Fig. $2 \mathrm{H}$ ). Given that neuronal AMPARs are expressed exclusively, if not all, in postsynaptic elements (Masugi-Tokita et al., 2007), these data predict cellular origins of respective GluA immunoreactivity in the molecular layer: GluA1 is mainly expressed in Bergmann glia and additionally in PCs, GluA2 and GluA3 are in PCs and interneurons, and GluA4 is mainly in Bergmann glia and additionally in interneurons. Therefore, a marked increase in immunoreactivity for GluA2 and GluA3 and a mild increase for GluA1 in the molecular layer of GluR $\delta 2-K O$ mice suggest the possibility that synaptic expression of AMPARs in PCs is increased in GluR $\delta 2-\mathrm{KO}$ mice.

\section{Target- and input-dependent regulations of synaptic}

\section{GluA subunits}

Next, we investigated this issue by postembedding immunogold electron microscopy. Synaptic localization of four GluA subunits was examined at three major excitatory synapses in the molecular layer, i.e., PF-PC synapse, CF-PC synapse, and PF-interneuron synapse. To identify the source of inputs, we used double immunogold labeling for GluA subunits and terminal markers: VGluT1 for PF terminals and VGluT2 for CF terminals (Miyazaki et al., 2003). Moreover, PF-PC and PF-interneuron synapses were distinguished by VGluT1-labeled synapses made onto dendritic spines or shafts, respectively. As we could not distinguish PF synapses on Golgi cell dendrites from those on basket/stellate cell dendrites in the molecular layer, our observation and measurement on PF-interneuron synapses in the following analyses should also include PF-Golgi cell synapses to some extents. Representative images from control and GluR $\delta 2-\mathrm{KO}$ mice are shown in Figures 3 and 4 for GluA2 and GluA3 and in supplemental Figures S3 and S4 (available at www.jneurosci.org as supplemental material) for GluA1 and GluA4. Numerical data are summarized in Figure 6, supplemental Figures S5 and S6, and supplemental Tables S1 and S2, available at www.jneurosci.org as supplemental material.

First, we tested the specificity of immunogold labeling for GluA subunits, because GluA1-3 antibodies, which have been produced recently (Yamazaki et al., 2010) and used in the present study, gave much higher immunogold labeling than those produced previously (Takeuchi et al., 2005). No significant labeling was seen for any GluA subunits in the corresponding GluA-KO mice (Fig. 6, red columns; supplemental Fig. S2, available at www.jneurosci.org as supplemental material), indicating the specificity of immunogold labeling for each GluA subunit.

In control mice, we observed three features of synaptic immunogold labeling. First, immunogold labeling that was significantly higher than the background labeling was noted for GluA1-3 at PF-PC and CF-PC synapses, and for GluA2-4 at PF- 


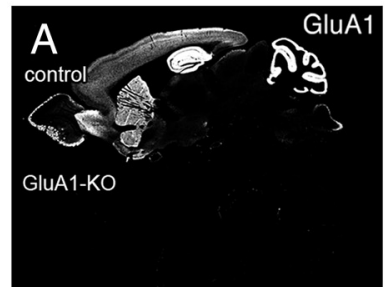

control
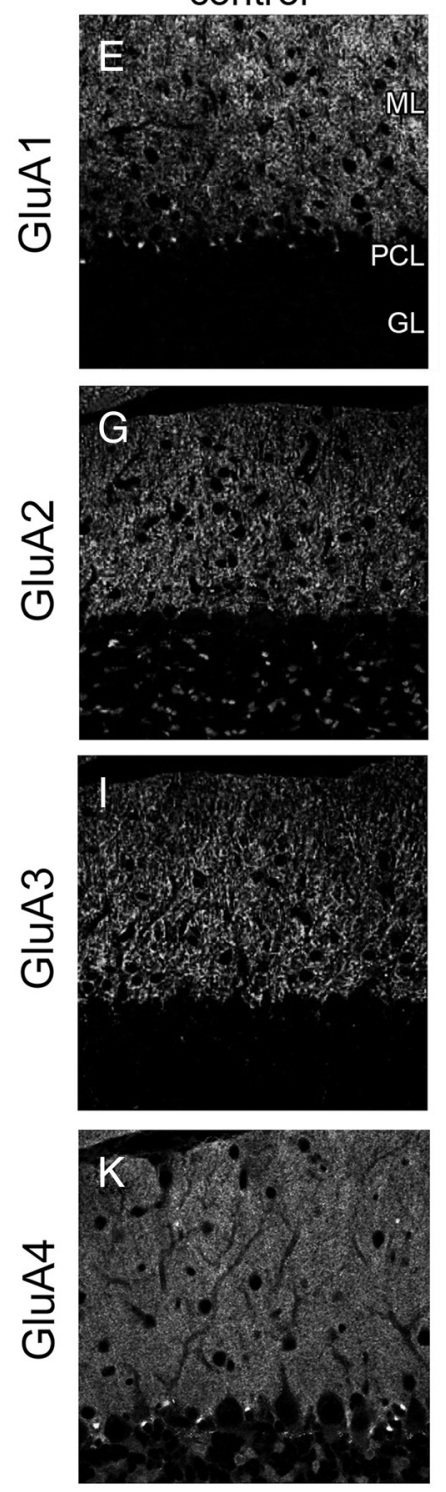

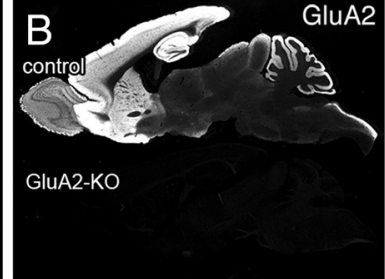

GluRס2-KO
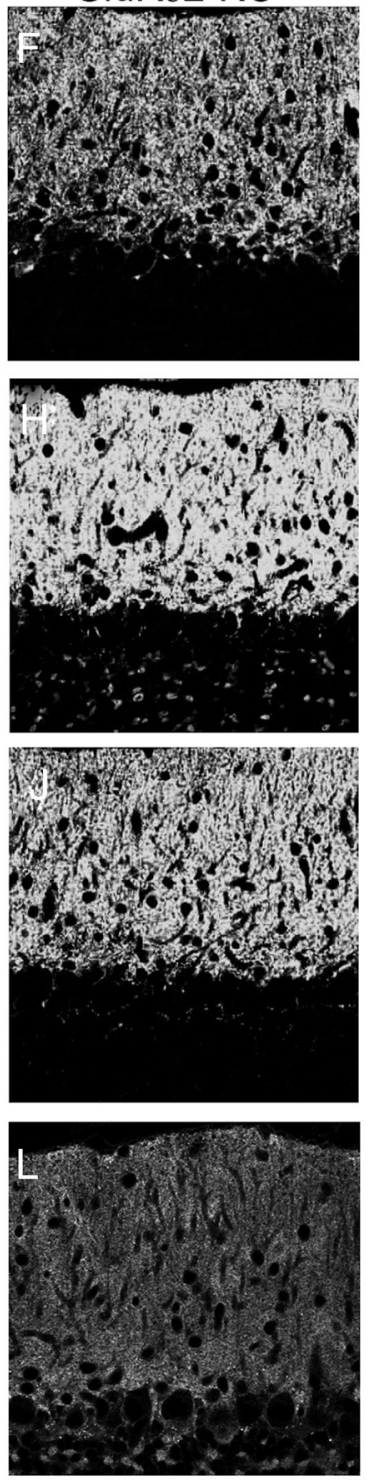

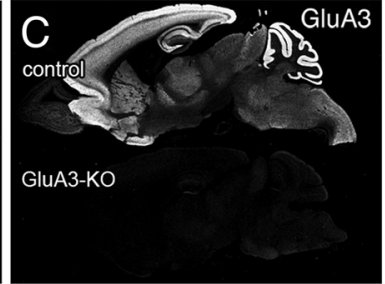

control
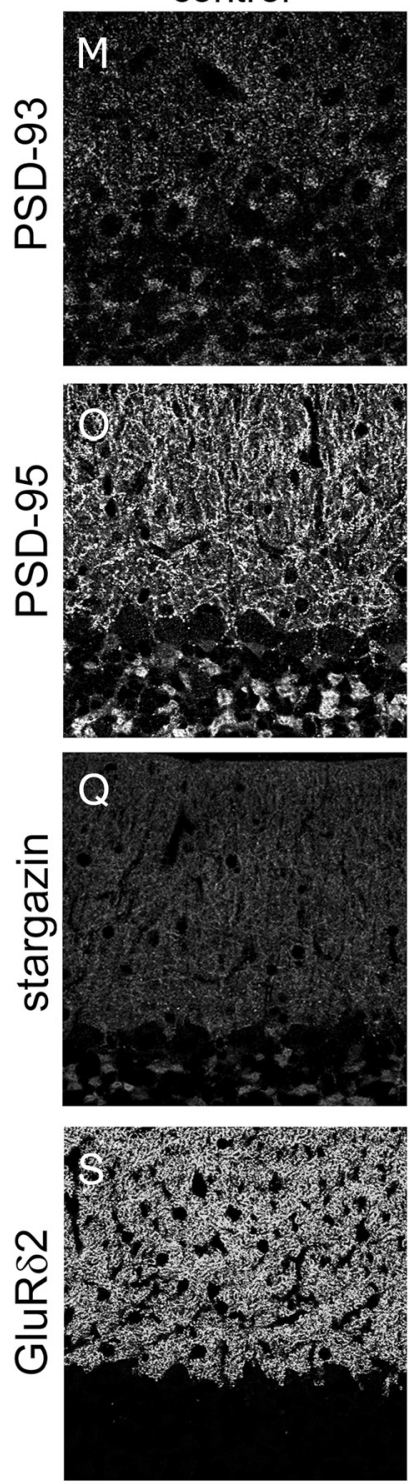

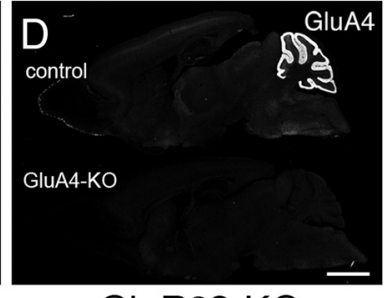

GluR $2-K O$
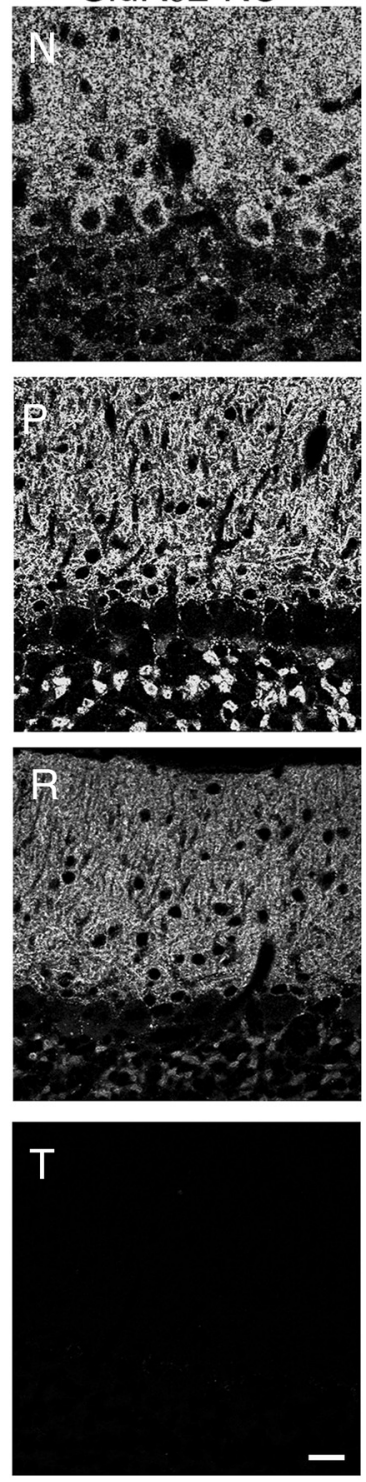

Figure 1. Specificity of GluA antibodies and immunofluorescence for GluA subunits and related postsynaptic molecules in the molecular layer of GluR $\delta 2-K 0$ and control mice. A-D, Light microscopic immunohistochemistry for four GluA subunits in parasagittal brain sections in wild-type control (upper) and corresponding GluA-KO (lower) mice. Note almost blank immunolabeling in corresponding GluA-KO brains. $E-L$, Immunofluorescence for GluA1-4 in control and GluR $\delta 2-K 0$ mice. Note a marked increase for GluA2 and GluA3, and a mild increase for GluA1 in the molecular layer of GluR $\delta 2-K 0$ mice. Images from control and GluR $\delta 2-K 0$ mice were captured at the same gain levels for each molecule. $\boldsymbol{M}-\boldsymbol{R}$, Immunofluorescence for PSD-93, PSD-95, and stargazin showing a drastic increase in the molecular layer of GluR $\delta 2-K 0$ mice without affecting those in the granular layer. $S, T, G$ luR $\delta 2$ is exclusively expressed in the molecular layer of control mice, but is completely

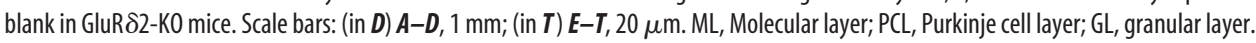

interneuron synapses (Figs. $3 A, C, 4 A, C, 6 A-D$; supplemental Fig. S3 $A, C$, available at www.jneurosci.org as supplemental material). These combinations were consistent with those of GluA mRNAs expressed in PCs or interneurons, respectively (Fig. 2E-H) (Keinänen et al., 1990; Pellegrini-Giampietro et al., 1991; Burnashev et al., 1992; Lambolez et al., 1992). Second, between the two excitatory synapses in PCs, the density of postsynaptic labeling for GluA1-3 was four to six times lower at PF synapses than that at CF synapses (Fig. 6A-C; supplemental Table S1, available at www.jneurosci.org as supplemental material). For example, the mean number of immunogold for GluA2 per $1 \mu \mathrm{m}$ PSD was $4.7 \pm 6.5$ (mean \pm SD) at PF-PC synapses (Figs. $3 A, 4 A$, $6 B$ ), whereas it was $21.5 \pm 11.5$ at CF-PC synapses (Fig. $4 A, 6 B$ ), showing significant difference $(p<0.001 ; U$ test $)$. This was also 

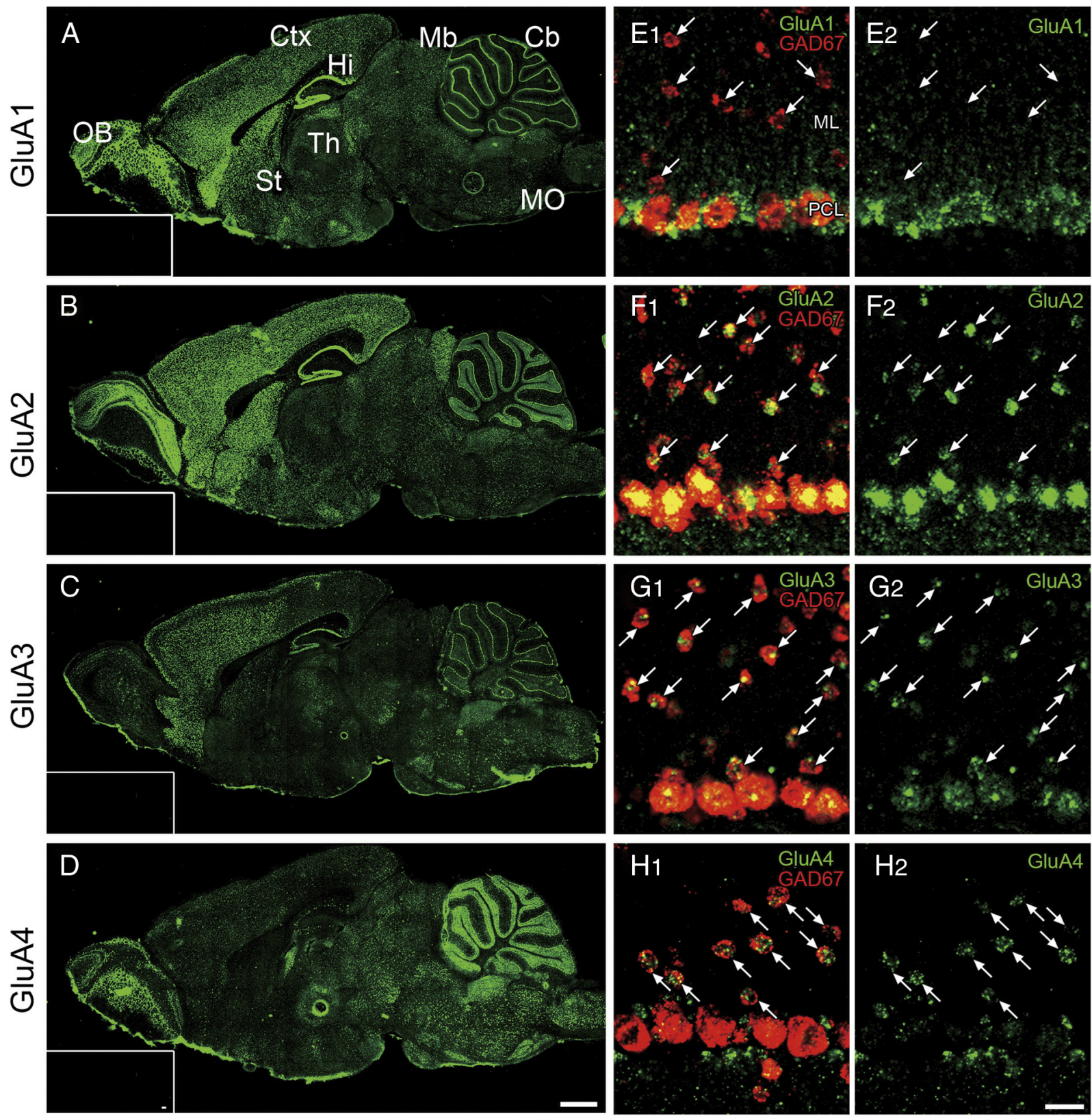

Figure 2. Fluorescent in situ hybridization showing distinct patterns of GluA mRNA expression in Purkinje cells and basket/stellate cells. $A-D$, Single fluorescent in situ hybridization for GluA1-4 in the adult mouse brain. Hybridization with sense probes gives no significant signals (insets). $\boldsymbol{E}-\boldsymbol{H}$, Double fluorescent in situ hybridization for GluA1-4 (green) and GAD67 (red) mRNAs in the cerebellar molecular layer. GluA1 mRNA is weak in GAD67 mRNA-positive large cells in PC layer (i.e., PCs), and almost absent in GAD67-positive small cells in the molecular layer (i.e., basket/stellate cells; arrows) (E). By contrast, GluA2 and GluA3 mRNAs are high in P(s and basket/stellate cells $(\boldsymbol{F}, \boldsymbol{G})$. GluA4 mRNA is moderately expressed in basket/stellate cells (H). GluA1 and GluA4 mRNAs between $\mathrm{PCS}$ represent expression in Bergmann glia, because these hybridizing signals were overlapped with those for glutamate transporter GLAST known to be enriched in this glia (data not shown). OB, Olfactory bulb; Ctx, cerebral cortex; St, striatum; Hi, hippocampus; Th, thalamus; Mb, midbrain; Cb, cerebellum; MO, medulla oblongata; ML, molecular layer; PCL, Purkinje cell layer. Scale bars: (in D) $\boldsymbol{A}-\boldsymbol{D}, 1 \mathrm{~mm}$; (in $\boldsymbol{H}_{\mathbf{2}}$ ) $\boldsymbol{E}-\boldsymbol{H}, 20 \mu \mathrm{m}$.

the case for GluA1 (PF-PC, $1.7 \pm 3.7$; CF-PC, $6.3 \pm 6.9$ ) (Fig. 6A; supplemental Figs. S3A, S4A, available at www.jneurosci.org as supplemental material) and for GluA3 (PF-PC, $3.0 \pm$ 5.5; CF-PC, $17.7 \pm 10.6$ ) (Figs. 3C, 4C, 6C). Moreover, coefficient of variation of the labeling density for each subunit was larger at PF synapses than at CF synapses, indicating that the postsynaptic labeling is more variable in the former synapses (supplemental Table S1, available at www.jneurosci.org as supplemental material). Third, the labeling density for GluA3 at PF synapses was four times lower in PCs than in interneurons (PF-interneuron synapse, $14.0 \pm 11.2 ; p<0.001$ ) (Figs. 3C, 6C). Therefore, these features indicate target cell type- and input pathway-dependent regulations of individual AMPAR subunits in the cerebellar molecular layer. Our observations are essentially consistent with a study by MasugiTokita et al. (2007); SDS-digested freeze-fracture replica labeling with use of pan-AMPAR antibody has revealed that AMPAR density is five times lower and more variable at PF-PC synapses than at CF-PC and PF-interneuron synapses in the adult rat cerebellum.

\section{Robust increase of GluA1-3 at GluR $\delta$ 2-KO PF synapses}

While virtually all PC spines make synapses with PF terminals in control mice, only $60 \%$ of PC spines make synaptic contact with 


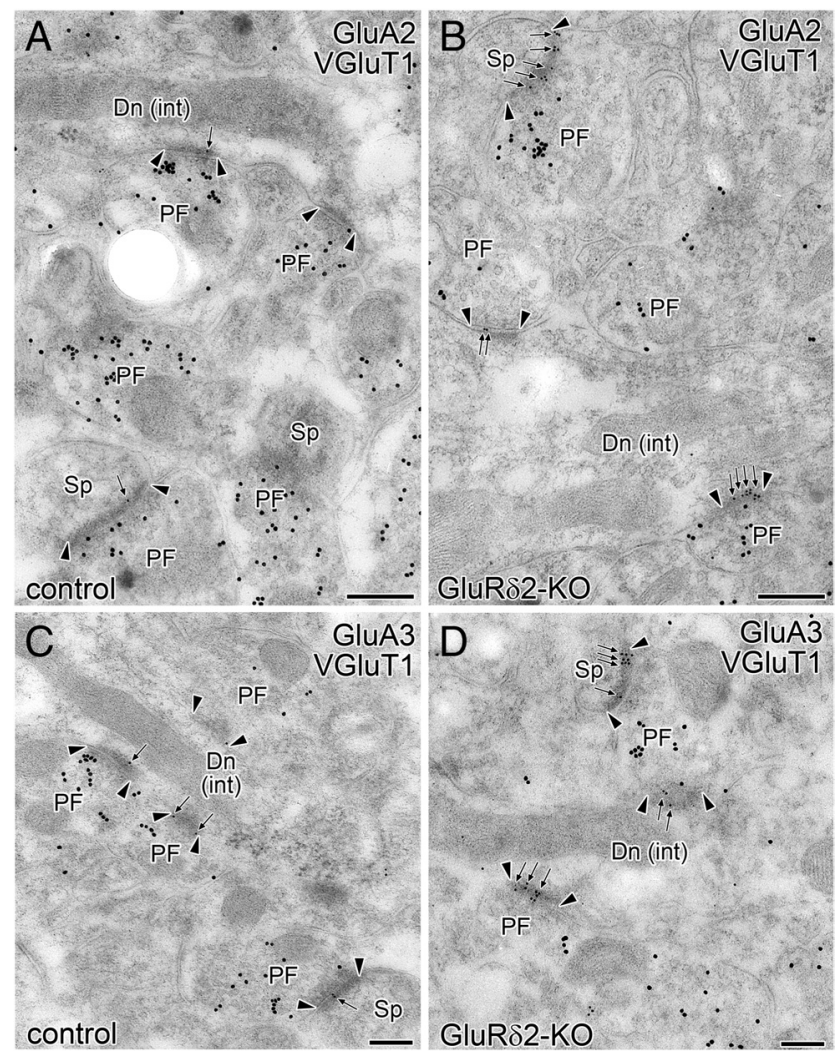

Figure 3. Robust increase of postsynaptic labeling for GluA2 and GluA3 at PF synapses in GluR $\delta 2-K 0 \mathrm{PCs}$ and interneurons. $A, B$, Double-labeling postembedding immunogold for GluA2 $(\phi=10 \mathrm{~nm})$ and VGluT1 $(\phi=15 \mathrm{~nm})$, the latter being a neurochemical marker for PF terminals. In control mice, asymmetrical synapses between VGluT1-labeled PF terminal (PF) and PC spine (Sp), and those between PF terminal and dendritic shaft of interneurons [Dn (int)] are only occasionally labeled for GluA2 (arrows) (A). However, GluA2 labeling at PF-PC synapses is robustly increased in GluR $\delta 2-K 0$ mice $(\boldsymbol{B})$. $\boldsymbol{C}, \boldsymbol{D}$, Double-labeling postembedding immunogold for GluA3 $(\phi=10 \mathrm{~nm})$ and VGluT1 $(\phi=15 \mathrm{~nm})$. GluA3 labeling at PF-PC synapses is also robustly increased in GluR $\delta 2-K 0$ mice (D). Edges of PSD are indicated by arrowheads. Numerical data are summarized in Figure 6, supplemental Figures $\mathrm{S5}$ and $\mathrm{S6}$, and supplemental Tables $\mathrm{S1}$ and S2, available at www.jneurosci.org as supplemental material. Scale bars, $200 \mathrm{~nm}$.

PF terminals in GluR $\delta 2-\mathrm{KO}$ mice and the rest are present as free spines (Kurihara et al., 1997). By conventional serial electron microscopy, we measured the PSD area of PF-PC synapses and found no significant difference in the mean PSD area, as follows: $0.09 \pm 0.03 \mu \mathrm{m}^{2}$ in control mice (53 synapses from two mice) and $0.10 \pm 0.04 \mu \mathrm{m}^{2}$ in GluR $\delta 2-\mathrm{KO}$ mice (46 synapses from two mice; $p=0.20, U$ test). We thus compare synaptic GluA contents between control and GluR $\delta 2-\mathrm{KO}$ mice by measuring the density of postsynaptic labeling, i.e., the number of immunogold particles per $1 \mu \mathrm{m}$ PSD. In GluR $\delta 2-\mathrm{KO}$ mice, we found that the density of postsynaptic labeling for GluA1-3 was drastically increased at PF-PC synapses (Fig. 6A-C; supplemental Fig. S5A-C, available at www.jneurosci.org as supplemental material), as follows: the mean density was increased to $294 \%$ of that in control mice for GluA1 (5.0 \pm 6.3 particles $/ \mu \mathrm{m}, p<0.001$ ) (Fig. $6 A$; supplemental Figs. $\mathrm{S} 3 B, \mathrm{~S} 4 B$, available at www.jneurosci.org as supplemental material), $300 \%$ for GluA2 (14.1 $\pm 9.2, p<0.001)$ (Figs. $3 B, 4 B, 6 B)$, and $567 \%$ for GluA3 $(17.0 \pm 11.4, p<0.001)$ (Figs. $3 D, 4 D, 6 C)$. By contrast, none of these subunits were significantly increased at CF-PC synapses (Figs. $4 B, D, 6 A-C$; supplemental Figs. $\mathrm{S} 4 B, \mathrm{~S} 5 A-C$, available at www.jneurosci.org as supplemental material), as follows: GluA1, $5.0 \pm 6.5, p=0.38$; GluA2, $19.9 \pm 12.4, p=0.38$; GluA3, $15.9 \pm 11.7, p=0.32$.

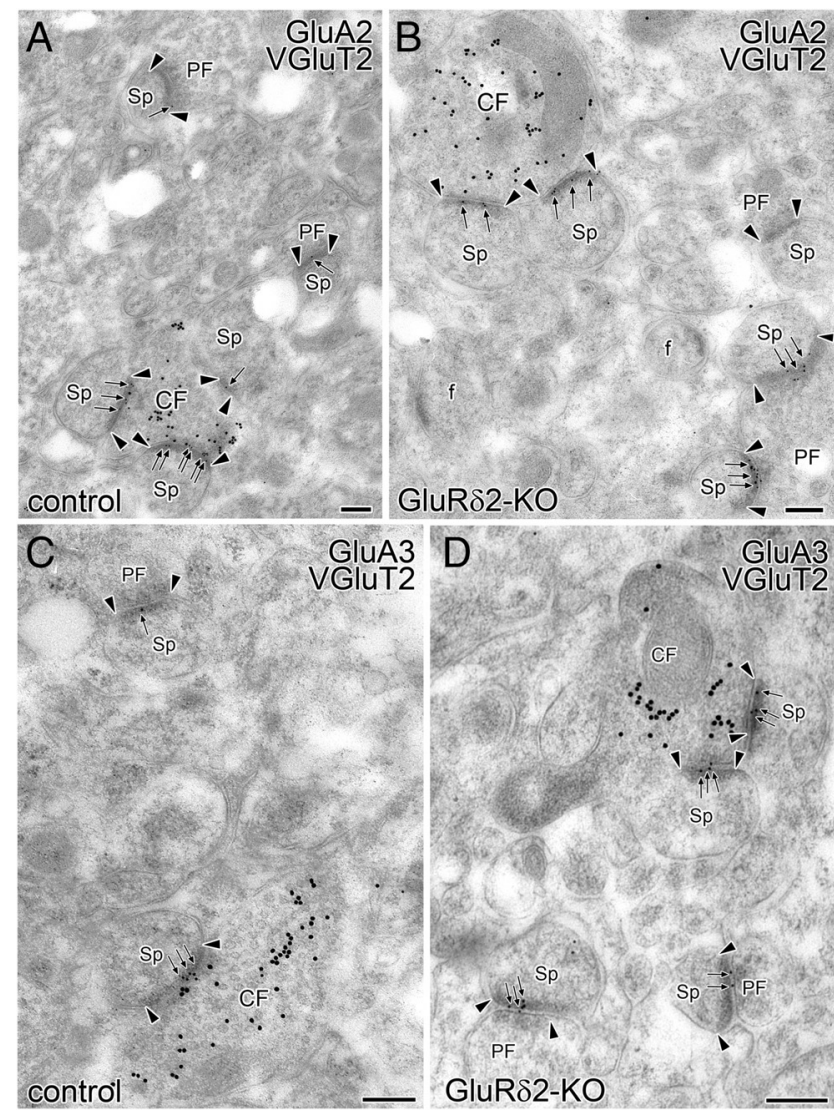

Figure 4. Unchanged postsynaptic labeling for GluA2 and GluA3 at CF synapses in GluR $\delta 2-K 0 ~ P C S . A, B$, Double-labeling postembedding immunogold for GluA2 ( $\phi=10 \mathrm{~nm}$ ) and VGluT2 $(\phi=15 \mathrm{~nm})$, the latter being a neurochemical marker for CF terminals. $C, D$, Double-labeling postembedding immunogold for GluA3 $(\phi=10 \mathrm{~nm})$ and VGluT2 $(\phi=15$ $\mathrm{nm})$. In control mice, GluA2 or GluA3 labeling at synapses between VGluT2-labeled (F terminal (CF) and PC spine (Sp) is clearly higher than those in VGluT2-unlabeled PF-PC synapses ( $A, C$. In GluR $\delta 2-K 0$ mice, while GluA2 or GluA3 labeling at PF-PC synapses is robustly increased, that at CF-PC synapses remains unaffected $(\boldsymbol{B}, \boldsymbol{D})$. Numerical data are summarized in Figure 6 , supplemental Figures $\mathrm{S} 5$ and $\mathbf{S 6}$, and supplemental Tables $\boldsymbol{S 1}$ and $\mathbf{S}$, available at www.jneurosci.org as supplemental material. Scale bars, $200 \mathrm{~nm}$.

Labeling for GluA4 remained at the background level at both PF-PC and CF-PC synapses (Fig. 6D; supplemental Figs. S3D, S4D, S5D, supplemental Table S2, available at www.jneurosci. org as supplemental material). Unexpectedly, we also found a moderate and significant increase in GluA2 and GluA3 labeling at PF-interneuron synapses (Fig. 6B, $C$; supplemental Fig. $\mathrm{S} 6 B, C$, available at www.jneurosci.org as supplemental material), as follows: $203 \%$ of that in control mice for GluA2 $(12.2 \pm 11.1, p<0.001)$ (Fig. $3 B$ ) and $167 \%$ for GluA3 (23.5 \pm 16.6, $p<0.001$ ) (Fig. 3D). At this synapse, the density of GluA1 and GluA4 labeling remained unchanged (Fig. 6A,D), as follows: GluA1, $1.0 \pm 2.9, p=0.53$ (supplemental Fig. S3B, available at www.jneurosci.org as supplemental material); GluA4, $14.8 \pm 9.9, p=0.73$ (supplemental Figs. S3D, S6A, $D$, available at www.jneurosci.org as supplemental material). These results demonstrate that GluR $\delta 2$ ablation does increase GluA1-3 at PF-PC synapses, and also increase GluA2 and GluA3 at PF-interneurons in a subunit-dependent manner. Thus, a marked increase in immunofluorescent labeling for GluA1-3 in the molecular layer of GluR $\delta 2-\mathrm{KO}$ mice reflects their increased expression at PF synapses in PCs and interneurons (Fig. 1E-J). 


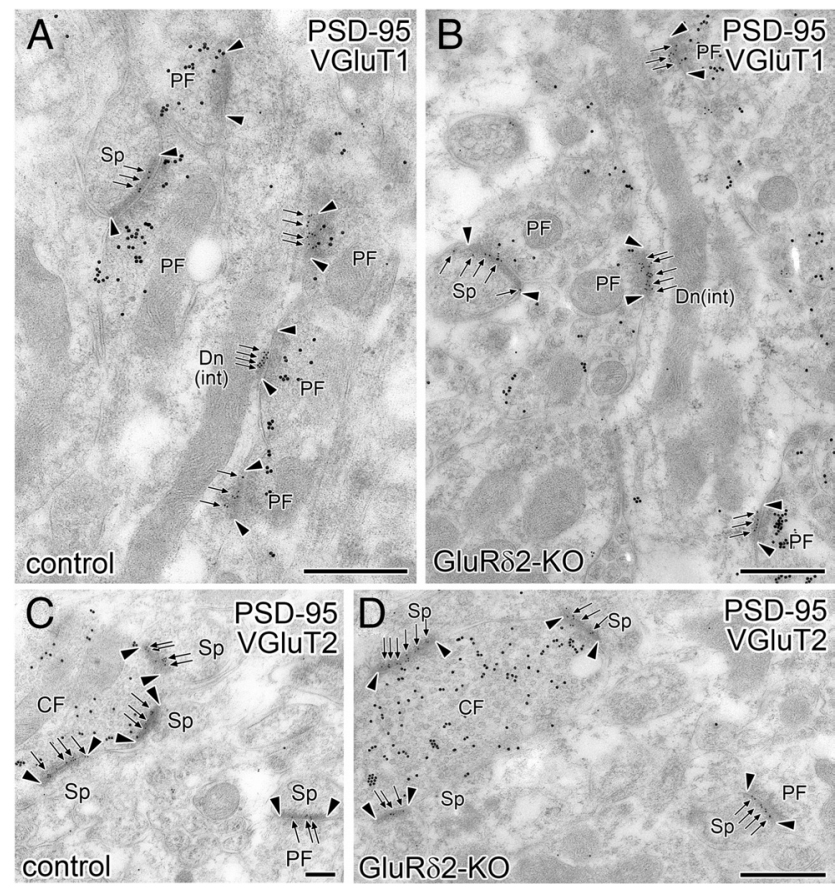

Figure 5. Increased postsynaptic labeling for PSD-95 at PF synapses in GluRס2-KO PCs and interneurons. $A, B$, Double-labeling postembedding immunogold for PSD-95 $(\phi=10 \mathrm{~nm})$ and VGluT1 $(\phi=15 \mathrm{~nm})$. Compared with control mice, postsynaptic labeling for PSD-95 at PF synapses on $P C$ spines (Sp) and interneuron dendrites [Dn (int)] is markedly increased in GluR $\delta 2-K 0$ mice. C, $D$, Double-labeling postembedding immunogold for PSD-95 ( $\phi=10 \mathrm{~nm}$ ) and VGluT2 ( $\phi=15 \mathrm{~nm}$ ). While PSD-95 labeling in PF-PC synapses is clearly increased, that in VGluT2-positive CF-PC synapse remains unaffected in GluR $\delta 2-K 0$ mice. Numerical data are summarized in Figure 6, supplemental Figures $S 5$ and $\$ 6$, and supplemental Tables $\mathrm{S1}$ and $\mathrm{S2}$, available at www.jneurosci.org as supplemental material. Scale bars, $200 \mathrm{~nm}$.

Next, we asked whether the increase of synaptic AMPARs is a phenomenon common to mutant mice defective in LTD at PF synapses in PCs (PF-LTD), such as mGluR1-KO mice (Aiba et al., 1994; Kano et al., 1997) and GluR $\delta 2 \Delta \mathrm{T}$ mice, which lack the C-terminal 7 aa of GluR $\delta 2$ termed the T site (Uemura et al., 2007). However, we found no significant increase in the density of GluA2 labeling in mGluR1-KO mice (control, $5.1 \pm 7.1$ particles/ $\mu \mathrm{m}$, coefficient of variation of $1.4, n=148$ synapses; mGluR1-KO, $6.2 \pm 11.0,1.8, n=122 ; p=0.37, U$ test) or in GluR $\delta 2 \Delta$ T mice (control, $5.5 \pm 8.6,1.6, n=48$; GluR $\delta 2 \Delta \mathrm{T}, 4.9 \pm 7.6,1.5, n=32$; $p=0.74)$. Thus, the increase of synaptic AMPARs is not common to PF-LTD-deficient mutants, but specific to GluR $\delta 2-\mathrm{KO}$ mice.

\section{PSD-93, PSD-95, and stargazin also increase at GluR $\delta 2-\mathrm{KO}$ PF synapses}

In the hippocampus, the number of synaptic AMPAR is determined by specific interaction with their interacting proteins PSD-95 and stargazin (Schnell et al., 2002; Stein et al., 2003; Ehrlich and Malinow, 2004). In the cerebellum, PSD-95 and stargazin are expressed in both PCs and basket/stellate cells (Fukaya and Watanabe, 2000; Yamazaki et al., 2010), and PSD-93 is predominantly expressed in PCs (Fukaya et al., 1999; Roche et al., 1999; McGee et al., 2001). We examined whether the increase of synaptic GluA expression accompanied that of such interacting proteins in GluR $\delta 2-\mathrm{KO}$ mice. A robust increase in immunofluorescence signal was also evident for PSD-93, PSD-95, and stargazin in the molecular layer of Glu $\delta 2-\mathrm{KO}$ mice (Fig. $1 M-R$ ). Postembedding immunogold electron microscopy clarified a significant increase in the labeling density for PSD-93, PSD-95, and
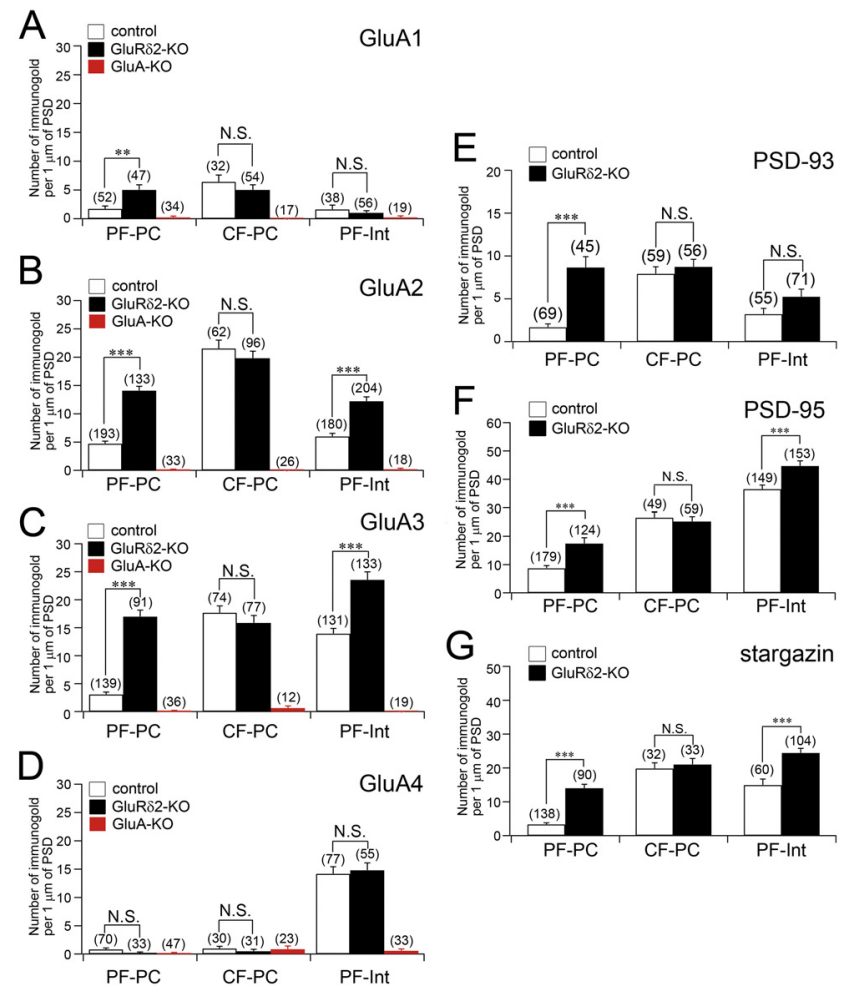

Figure 6. Quantitative analyses on labeling density of GluA1-4, PSD-93, PSD-95, and stargazin at three types of excitatory synapses in the cerebellar molecular layer. $\boldsymbol{A}-\boldsymbol{D}$, In both control (white bars) and GluR $\delta 2-K 0$ (black bars) mice, the combination of GluA subunits expressed is GluA1-3 at PF-PC and CF-PC synapses, and GluA2-4 at PF-interneuron synapses. The specificity of postsynaptic labeling for GluA subunits is confirmed by almost blank labeling in corresponding GluA-K0 mice (red bars). $\boldsymbol{E}-\mathbf{G}$, In GluR $\delta 2-K 0$ mice, labeling density for PSD-93, PSD-95, and stargazin is markedly increased at PF synapses in PCs and interneurons, but not at CF-PC synapses. Error bars represent SEM. Numbers of analyzed synapses are indicated in parentheses. Mann-Whitney U test; ${ }^{*} p<0.05 ;{ }^{* *} p<0.01$; ${ }^{* * *} p<0.001$; N.S., not significant $(p>0.05)$.

stargazin at PF-PC synapses (Fig. 6E-G; supplemental Fig. S5E-G, available at www.jneurosci.org as supplemental material), as follows: $511 \%$ of that in control mice for PSD-93 (8.7 \pm 8.6, $p<0.001$ ) (Fig. $6 E$ ), 200\% for PSD-95 (17.4 $\pm 14.7, p<$ $0.001)$ (Fig. $6 F)$, and $424 \%$ for stargazin $(14.0 \pm 11.4 ; p<0.001)$ (Fig. 6G). A mild but significant increase was found at PFinterneurons synapses for PSD-95 and stargazin, but not for PSD-93 (Fig. 6E-G; supplemental Fig. S6E-G, available at www. jneurosci.org as supplemental material), as follows: $122 \%$ of that in control mice for PSD-95 (44.7 $\pm 22.9 ; p<0.001)$ (Fig. $6 F)$ and $164 \%$ for stargazin $(24.4 \pm 14.0 ; p<0.001)$ (Fig. $6 G)$. By contrast, we found no significant changes at CF-PC synapses (Fig. $6 E-G$; supplemental Fig. S5E-G, supplemental Tables S1, 2, available at www.jneurosci.org as supplemental material). Therefore, in GluR $\delta 2-\mathrm{KO}$ mice, AMPAR-interacting proteins are also increased at PF synapses in PCs and interneurons.

\section{Expression of GluR $\delta 2$ at PF-interneuron synapses}

GluR $\delta 2$ has been reported to be absent not only at CF-PC synapses, but also at PF-interneuron synapses (Landsend et al., 1997). Nevertheless, we found a modest increase of GluA subunits and their interacting proteins at PF-interneuron synapses. To solve this discrepancy, we reinvestigated cellular expression of GluR $\delta 2$. Consistent with previous in situ hybridization using radiolabeled probes (Araki et al., 1993; Lomeli et al., 1993; Takayama et al., 1996), antisense riboprobe revealed that GluR $\delta 2$ 

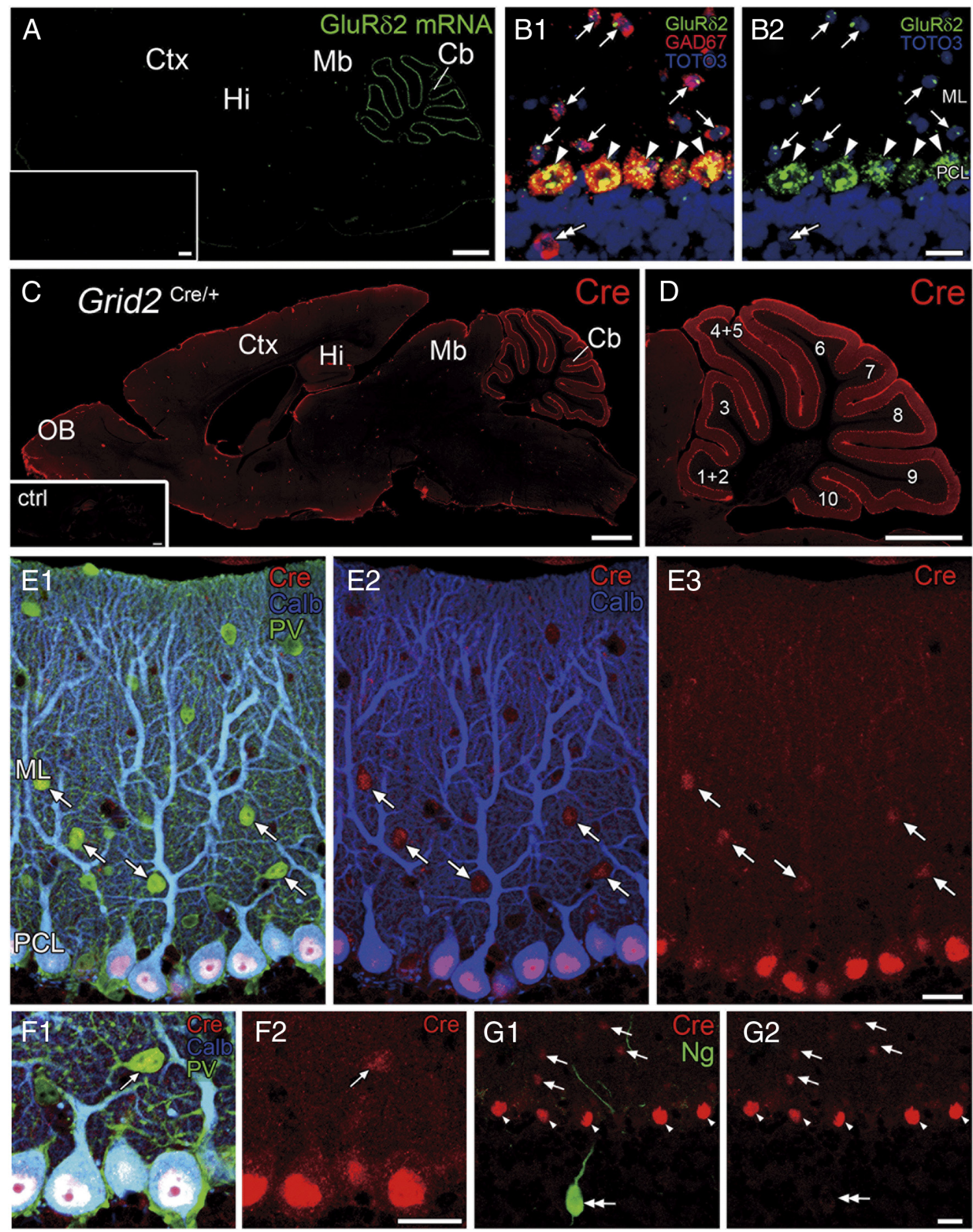

Figure 7. GluR $\delta 2 \mathrm{mRNA}$ and promoter activity are detected highly in $\mathrm{PCs}$ and weakly in basket/stellate cells. $A$, Fluorescent in situ hybridization showing exclusive expression of GluR $\delta 2 \mathrm{mRNA}$ (green) in the cerebellum in the adult mouse brain. Note that sense probe yields no specific labeling (inset). B, Double-labeling fluorescent in situ hybridization for GluR $\delta 2$ (green) and GAD67 (red) mRNAs. In addition to heavy labeling in PCs (arrowheads), GAD67 mRNA-positive interneurons in the molecular layer (arrows) are consistently labeled for one of two tiny punctate signals for GluR $\delta 2$ mRNA. No such labeling is seen for GAD67 mRNA-positive interneurons in the granular layer (double arrowhead). C, D, Immunofluorescence for Cre recombinase in Grid2 ${ }^{\text {Cre/+ }}$ mice. No significant staining is observed in the brain of control mice (inset). $E$, $F$, Triple immun ofluorescence for (re recombinase (red), calbindin (blue), and parvalbumin (PV, green) in the molecular layer of Grid2 ${ }^{\text {Cre/ }+}$ mice. Intense immunolabeling for Cre recombinase is observed in the nucleus of calbindin/parvalbumin-positive PCs, while weak labeling is also detected in the nucleus of calbindin-negative/ parvalbumin-positive interneurons in the molecular layer (arrows in $\boldsymbol{E}, \boldsymbol{F}) . \mathbf{G}$, № Cre recombinase (red) is detected in neurogranin ( $\mathrm{Ng}$, green)-positive Golgi cell (double arrow). OB, 0lfactory bulb; Ctx, cerebral cortex; Mb, midbrain; Cb, cerebellum; ML, molecular layer; PCL, Purkinje cell layer. Scale bars: $A, C, D, 1 \mathrm{~mm} ; \boldsymbol{B}, \boldsymbol{E}-\mathbf{G}, 20 \mu \mathrm{m}$.

mRNA was preferentially expressed in the cerebellum throughout postnatal development (Fig. 7A; supplemental Fig. S7 A, C,E, available at www.jneurosci.org as supplemental material) and detected in GAD67 mRNA-positive cells in the PC layer, i.e., PCs (Fig. 7B; supplemental Fig. S7 B, D,F, available at www.jneurosci. org as supplemental material). Use of the sense probes yielded no significant signals (Fig. $7 A$, insets). Furthermore, we consistently found one or two tiny clusters of hybridizing signals in GAD67 mRNA-positive interneurons in the molecular layer (Fig. $7 B$ ). In postnatal development, the expression in molecular layer in- 
terneurons first became evident at postnatal day 14 (supplemental Fig. S7 B, D, F, available at www.jneurosci.org as supplemental material). No significant signals were discerned in the granular layer (Fig. 7B; supplemental Fig. S7D,F, available at www. jneurosci.org as supplemental material). These spatiotemporal profiles of GluR $\delta 2 \mathrm{mRNA}$ expression were faithfully reproduced by $\beta$-galactosidase histochemistry in a reporter mouse line (supplemental Fig. S8 A-L, available at www.jneurosci.org as supplemental material), in which the Grid $2^{\mathrm{cre} /+}$ mouse line was crossed with the Cre-inducible lac $Z$ reporter mouse line.

Using the Grid2 ${ }^{\text {cre/+ }}$ mouse, we further assessed GluR $\delta 2$ promoter activity by immunofluorescence for Cre recombinase. While no significant staining was observed in the brain of control mice (Fig. 7C, inset), Cre immunoreactivity was clearly noted in the cerebellum of Grid2 ${ }^{\mathrm{Cre} /+}$ mice (Fig. 7C,D). Within the cerebellum, the most intense immunolabeling was observed in the nucleus of PCs (Fig. 7 E, F). Furthermore, weak labeling was consistently detected in the nucleus of parvalbumin-expressing interneurons in the molecular layer (Fig. 7E,F). By contrast, Cre immunoreactivity was below the detection threshold in other cerebellar neurons, i.e., neurogranin-positive Golgi cells (Fig. $7 G$ ), mGluR1-expressing unipolar brush cells (supplemental Fig. S8 $M$, available at www.jneurosci.org as supplemental material), and neurons in the deep cerebellar nuclei (supplemental Fig. S8 $N$, available at www.jneurosci.org as supplemental material). Thus, basket/stellate cells express GluR $\delta 2$ at the transcription level, though at much lower levels than PCs do.

Expression at the protein level was examined by doublelabeling postembedding immunogold electron microscopy (Fig. 8). Consistent with a previous study (Landsend et al., 1997), GluR $\delta 2$ was highly localized at PF-PC synapses labeled for VGluT1 (Fig. 8A), whereas no significant labeling was observed at CF-PC synapses labeled for VGluT2 (Fig. 8 B). At PF-PC synapses, all synapses examined (159 of 159 synapses) were labeled with more than two immunogold particles for GluR $\delta 2$. A few immunogold particles were frequently observed at PFinterneuron synapses (Fig. 8A). Synaptic distribution of GluR $\delta 2$ was quantitatively evaluated. On average, the density of immunogold labeling at PF-interneuron synapses amounted to $20 \%$ of that at PF-PC synapses. By contrast, the density at CF-PC synapses was almost equivalent to the background labeling as determined from GluR $\delta 2-\mathrm{KO}$ mice $(n=25$ and 43 synapses form control and GluR $\delta 2-\mathrm{KO}$ mice, respectively, $p=0.18$ ). The density at PF-PC and PF-interneuron synapses was much higher than that at the same types of synapses in GluR $\delta 2-\mathrm{KO}$ mice (Fig. $8 C, D$ ), showing significant differences ( $p<0.0001$ for each comparison) (Fig. $8 E$ ). Taken together, low but significant amounts of GluR $\delta 2$ are localized at PF synapses in basket/stellate cells.

\section{Formation of PF-interneuron synapse is normal in GluR $\delta 2 \mathrm{KO}$ mice}

The ablation of GluR $\delta 2$ causes two morphological changes at PF-PC synapses, i.e., mismatching between presynaptic and postsynaptic specializations and their disconnection leading to naked spines free of PF innervation (Guastavino et al., 1990; Kashiwabuchi et al., 1995; Kurihara et al., 1997; Lalouette et al., 2001). To determine whether GluR $\delta 2$ also plays a similar role in PFinterneuron synapses, we finally examined fine structure of PFinterneuron synapses using serial electron microscopy (Fig. 9). Interneuron dendrites have rather irregular contours and form asymmetrical synapses with PF terminals at a high density (Palay and Chan-Palay, 1974). In both GluR $\delta 2$ control and KO mice, virtually all PSDs on dendritic shafts of interneurons had synaptic

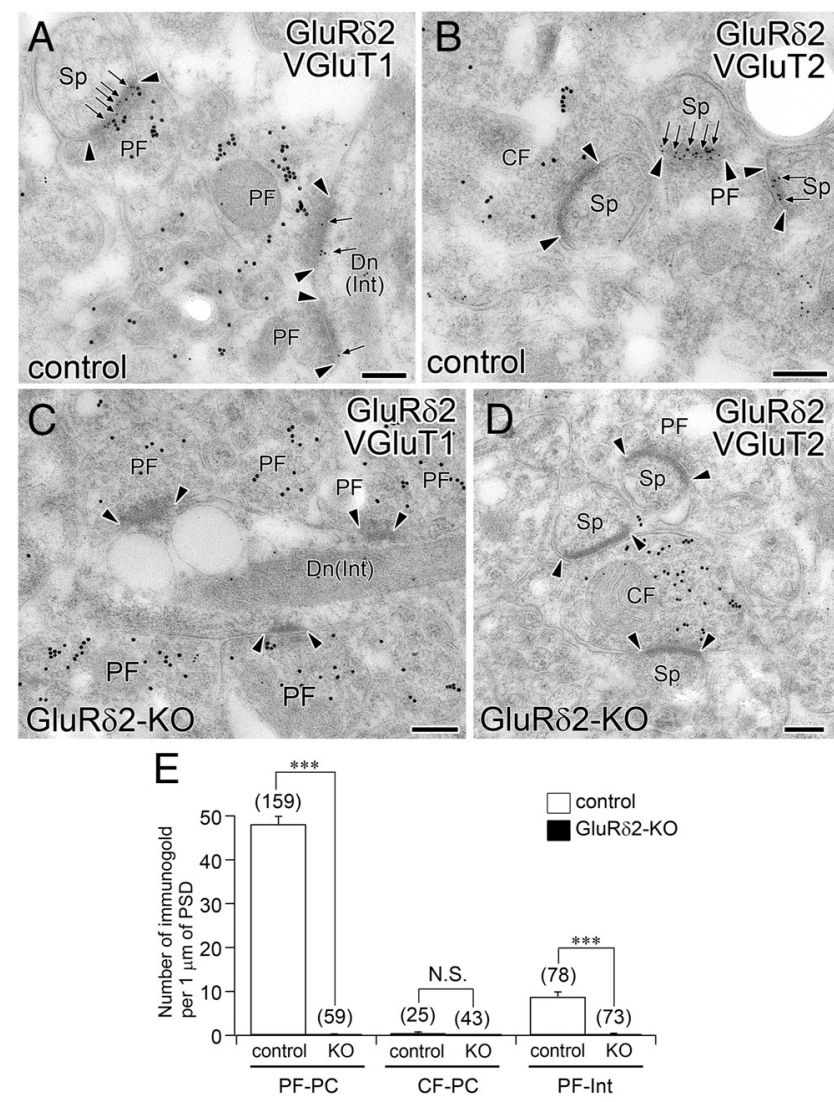

Figure 8. Low but significant postsynaptic labeling for GluR $\delta 2$ at PF-interneuron synapses Double labeling postembedding immunogold for GluR $\delta 2(\phi=10 \mathrm{~nm})$ and terminal markers ( $\phi=15 \mathrm{~nm}$ : VGluT1 in $\boldsymbol{A}$ and C, VGluT2 in $\boldsymbol{B}$ and $\boldsymbol{D}$ ). $\boldsymbol{A}, \boldsymbol{B}$, In control mice, GluR $\delta 2$ is exclusively localized at VGluT1-positive PF-PC synapses $(\boldsymbol{A})$, but not in VGluT2-positive CF-PC synapses $(\boldsymbol{B})$. PF-interneuron synapses are moderately labeled for GluR $\delta 2(\boldsymbol{A})$. C, D, Postsynaptic labeling for GluR $\delta 2$ almost completely disappears at PF synapses on PC spines (Sp) and interneuron dendrites [Dn (int)] in GluR $\delta 2-K 0$ mice. Edges of PSD are indicated by arrowheads. $\boldsymbol{E}$, Histograms showing labeling density for GluR $\delta 2$ at three excitatory synapses in control (white bars) and GluR $\delta 2-K 0$ (black bars) mice. On average, the density of immunogold labeling at PFinterneuron synapses amounts to $20 \%$ of that at PF-PC synapses. Numbers of synapses examined are indicated in parentheses. ${ }^{* * *} p<0.0001$, Mann-Whitney $U$ test. N.S., Not significant. Scale bars, $200 \mathrm{~nm}$.

contact with presynaptic counterparts, and their presynaptic and postsynaptic specializations were well matched (Fig. 9A, B1). We measured the maximal length of given PSDs and the density of asymmetrical synapses on interneuron dendrites. The mean maximal length of PSDs was comparable between control $(0.27 \pm 0.01 \mu \mathrm{m})$ and GluR $\delta 2-\mathrm{KO}(0.26 \pm 0.01 \mu \mathrm{m})$ mice, showing no significant difference ( $p=0.46 ; n=86$ and 108 synapses from three control and three GluR $\delta 2-K O$ mice, respectively). The mean density of asymmetrical synapses per $1 \mu \mathrm{m}$ of dendritic segment was compared using 3D-reconstructed shaft dendrites of interneurons (Fig. 9C,D). We found that the density of asymmetrical synapses was also comparable between control $(1.83 \pm 0.25)$ and GluR $\delta 2-K O(2.19 \pm 0.29)$ mice, showing no significant difference ( $p=0.41 ; n=4$ dendrites from two control and two GluR $\delta 2-\mathrm{KO}$ mice). Therefore, unlike PCs, PF synapses in interneurons are normally formed and maintained in the absence of GluR $\delta 2$.

\section{Discussion}

The majority of PF synapses in PCs yield no electrical responses (Barbour, 1993; Ekerot and Jörntell, 2001; Isope and Barbour, 2002), and these "silent" synapses are thought to be necessary for 

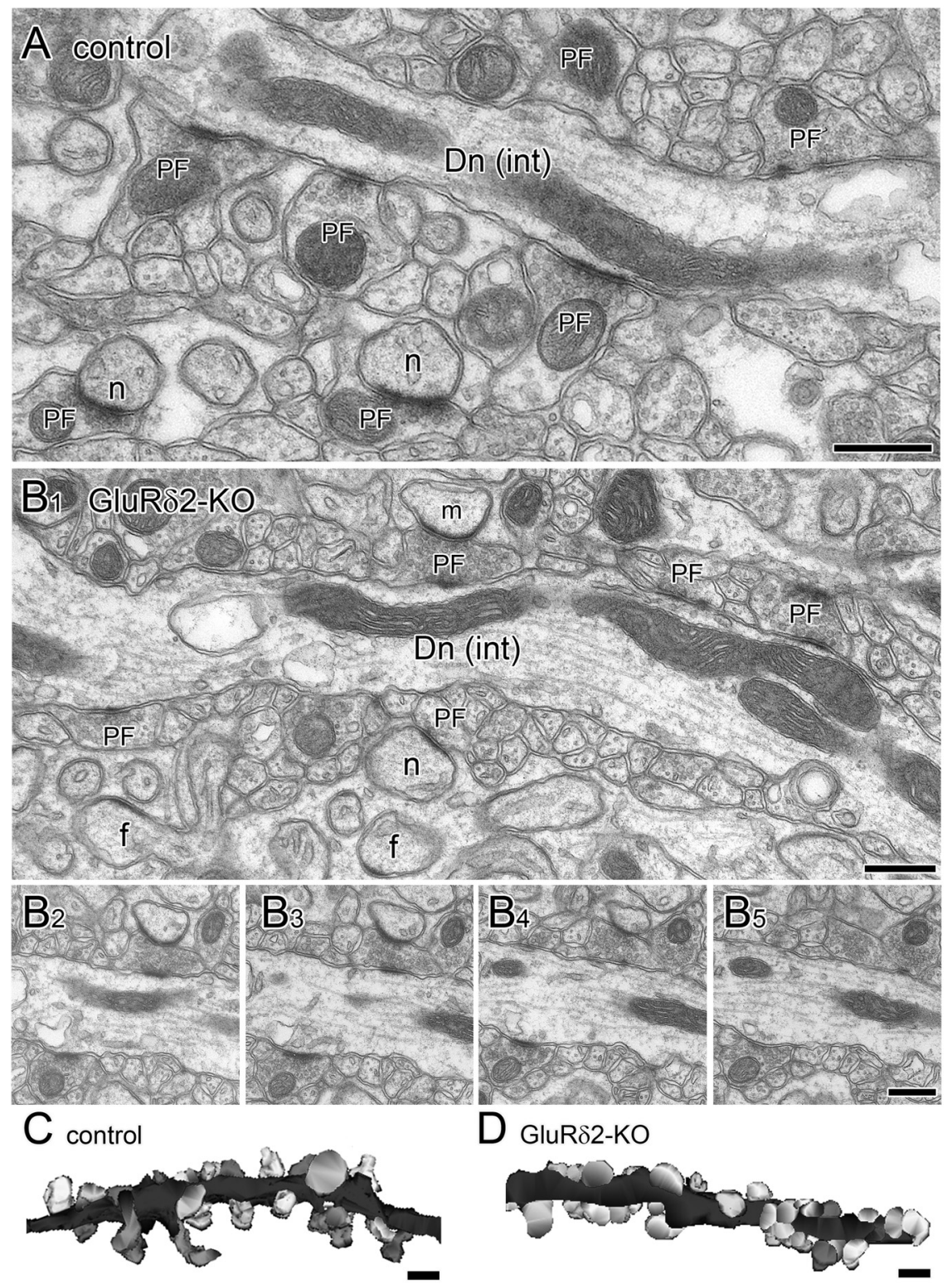

Figure 9. Density and size of PF-interneuron synapses are unaffected in GluR $\delta 2-K 0$ mice. $A, B$, Conventional electron microscopy. In both control $(\boldsymbol{A})$ and GluR $\delta 2-K 0(\boldsymbol{B})$ mice, virtually all PSDs on dendritic shafts of interneurons have presynaptic counterparts. In GluR $\delta 2-K 0$ mice, free spines ( $f$ ) having no presynaptic counterparts are numerous in the neuropil, and mismatched synapse $(m)$ that have disproportionally long PSD are observed on PC spines, but not on dendritic shafts of interneurons even using serial electron micrographs $\left(\boldsymbol{B}_{1-5}\right) . \boldsymbol{C}, \boldsymbol{D}$, Partial reconstruction of interneuron dendrites in the molecular layer. Scale bars, $200 \mathrm{~nm}$.

optimal learning and information storage (Brunel et al., 2004). In contrast, CF synapses are provided with high release probability and five times more AMPARs than PF synapses, making them highly reliable synapses (Foster et al., 2002; Masugi-Tokita et al., 2007). Thus, input pathway-dependent regulation of synaptic strength in PCs will be important for establishing optimal synaptic weight distribution. In the present study, we confirmed the biased AMPAR distribution between PF and CF synapses in PCs, and further disclosed a robust increase of AMPAR subunits at PF synapses in GluR $\delta 2-\mathrm{KO}$ mice.

\section{GluR $\delta 2$ is essential for input}

pathway-dependent AMPAR disparity in PCs

Consistent with previous studies (Keinänen et al., 1990; PellegriniGiampietro et al., 1991; Lambolez et al., 1992; Petralia et al., 1997),
GluA1-3 mRNAs were expressed in PCs (Fig. 2). By postembedding immunogold, we further showed high labeling for GluA2 and GluA3 and relatively low labeling for GluA1 at both PF and CF synapses in control PCs (Fig. 6). Because AMPAR-mediated EPSCs show little rectification and low $\mathrm{Ca}^{2+}$ permeability (Tempia et al., 1996; Momiyama et al., 2003), the majority of AMPARs in PCs contain GluA2. Therefore, the major AMPARs in PCs should be GluA2/GluA3 channels with additional GluA1/GluA2 channels. In control mice, PF synapses significantly differed from CF synapses in that GluA1-3 labeling in the former was four to six times lower than that in the latter, as follows: $27 \%$ of that at CF synapse for GluA1, 22\% for GluA2, and 17\% for GluA3. In GluR $82-K O$ mice, immunogold labeling for GluA1-3 displayed a three- to fivefold increase at PF synapses and consequently became comparable to that at $\mathrm{CF}$ synapses, as follows: $100 \%$ of that in control mice for GluA1, 71\% for GluA2, and 107\% for GluA3. Therefore, the loss of the biased synaptic distribution suggests that GluR $\delta 2$ is the molecular determinant for input pathway-dependent disparity of synaptic AMPARs in PCs. Considering that each of GluA1-3 was increased to similar extents at PF-PC synapses in GluR $\delta 2-\mathrm{KO}$ mice, GluR $\delta 2$ likely suppresses synaptic expression of GluA2/GluA3 and GluA1/GluA2 channels with similar potencies.

\section{Possible mechanisms for GluR $\delta 2$ - mediated regulation of synaptic AMPARs in PCs}

During PF-LTD, the number of postsynaptic AMPARs is reduced (Matsuda et al., 2000; Wang and Linden, 2000). Upon concomitant activation of CF and PF inputs, protein kinase $\mathrm{C}$ phosphorylates Ser- 880 at the C terminus of GluA2, which leads to the release of GluA2-containing AMPARs from its anchoring protein GRIP (glutamate receptor-interacting protein) and their subsequent endocytosis. Interestingly, application of GluR $\delta 2$ antibody against the putative ligand-binding domain induces AMPAR endocytosis, attenuates synaptic transmission, and abrogates PF-LTD in cultured PCs (Hirai et al., 2003). From these lines of evidence, we assume that increased AMPARs could link to defected AMPAR endocytosis or defected PF-LTD in GluR $\delta 2-K O$ mice (Kashiwabuchi et al., 1995). To pursue the latter possibility, we examined mGluR1-KO mice and GluR $\delta 2 \Delta \mathrm{T}$ mice as PF-LTD-deficient models, and found no significant increase in the density of GluA2 labeling. Thus, the increase of synaptic AMPARs is not common to PF-LTD-deficient mutants, but specific to GluR $\delta 2-\mathrm{KO}$ mice. Accordingly, the former possibility that increased AMPARs in GluR $\delta 2-K O$ mice is caused by defected AMPAR endocytosis remains to be solved in future studies. 
Following chronic blockade of neuronal activity, so-called homeostatic synaptic plasticity occurs, for example, as increased synaptic insertion of AMPARs (Gainey et al., 2009; Pozo and Goda, 2010). We next postulate that increased AMPARs might be a compensatory change for reduced number of PF synapses in GluR $\delta 2-K O$ PCs (Kashiwabuchi et al., 1995). Despite the number of PF synapses per PC being half in GluR $\delta 2-\mathrm{KO}$ mice (Kurihara et al., 1997), the frequency of simple spikes as well as complex spikes is normally maintained (Yoshida et al., 2004). Therefore, although homeostatic synaptic scaling by itself appears unlikely or insufficient as the sole underlying mechanism for increased AMPARs, facilitated synaptic insertion of AMPARs may contribute to maintain simple spike activities in GluR $\delta 2-\mathrm{KO}$ mice.

In the hippocampus, PSD-95 and related proteins are considered to be candidate molecules for slot or placeholder that delimits the number of synaptic AMPARs, through specific interactions with TARPs such as stargazin (Schnell et al., 2002; Stein et al., 2003; Ehrlich and Malinow, 2004). We demonstrated a concomitant increase of PSD-93 and PSD-95 at PF-PC synapses in GluR $\delta 2-K O$ mice, suggesting increased capacity for AMPARTARP complexes. Compared with AMPARs, GluR $\delta 2$ is much more efficiently transported to the cell surface, in part, due to strong endoplasmic reticulum exit signal in the C-terminal domain (Matsuda and Mishina, 2000; Matsuda et al., 2000; Yuzaki, 2009). In addition to PSD-93/95, GluR $\delta 2$ further binds to other scaffolding molecules, such as Delphilin, Shank, and S-SCAM (Roche et al., 1999; Uemura et al., 2004). Therefore, GluR $\delta 2$ appears to play a key role in the regulation of postsynaptic molecular organization and delimit the number of slots available for AMPARs at PF synapses through competition with AMPARs and related molecules for postsynaptic occupation.

\section{GluR $\delta 2$ also restricts the number of AMPARs at PF synapses in interneurons}

In basket/stellate cells, we detected hybridizing signals for GluA2-4 mRNAs (Fig. 2) and addressed their protein localization at PF synapses (Fig. 6). This cellular expression is consistent with previous in situ hybridization studies (Keinänen et al., 1990; Sato et al., 1993) and immunohistochemistry (Baude et al., 1994; Petralia et al., 1997). Under the resting conditions, PF-stellate cell synapses exhibit inwardly rectifying EPSCs, indicating the predominance of GluA2-lacking $\mathrm{Ca}^{2+}$-permeable AMPARs (Liu and Cull-Candy, 2000; Gardner et al., 2005). However, $\mathrm{Ca}^{2+}$ influx through GluA2-lacking AMPARs during high-frequency PF stimulation induces a rapid replacement with GluA2containing AMPARs (Liu and Cull-Candy, 2000, 2002; Gardner et al., 2005). Our present finding that PF-interneuron synapses richly express GluA2 may reflect such plasticity-associated incorporation into the synapses.

Unexpectedly, GluA2 and GluA3, but not GluA4, were increased by twofold at PF-interneuron synapses in GluR $\delta 2-\mathrm{KO}$ mice. This prompted us to reexamine the cellular and synaptic expression of GluR $\delta 2$. Although signal intensity was much lower than that in PCs, GluR $\delta 2$ mRNA and promoter activity were observed in basket/stellate cells (Fig. 7). Intriguingly, we have previously observed that Cbln1, which selectively interacts with the extracellular N-terminal domain of GluR $\delta 2$ to regulate the connectivity of PF-PC synapses (Hirai et al., 2005; Ito-Ishida et al., 2008; Matsuda et al., 2010; Uemura et al., 2010), is also localized in the synaptic cleft at PF-interneuron synapses (Miura et al., 2009). When subtracting the background labeling, labeling density for Cbln1 at PF-interneuron synapses also amounts to onefourth of that at PF-PC synapses [Miura et al. (2009), their Fig. 6].
These results suggest that GluR $\delta 2$ likely interacts with Cbln 1 at PF-interneuron synapses as well, and that GluR $\delta 2$ restricts the number of AMPARs at PF synapses in PCs and interneurons according to its amounts expressed.

However, unlike PF-PC synapses (Kashiwabuchi et al., 1995; Kurihara et al., 1997; Takeuchi et al., 2005), no apparent abnormalities were found in the density and size of PF-interneuron synapses in GluR $\delta 2-\mathrm{KO}$ mice (Fig. 9). Considering that approximately a half of PF-PC synapses remains in GluR $\delta 2-\mathrm{KO}$ mice (Kurihara et al., 1997), synaptic connectivity should also be controlled by other parallel mechanisms, which may sufficiently compensate in interneurons, but not in PCs, for the loss of GluR $\delta 2$ function.

Through the present study, we provide a novel role of GluR $\delta 2$, i.e., restricting the number of synaptic AMPARs at PF synapses in PCs and basket/stellate cells. At PF synapses, therefore, GluR $\delta 2$ strengthens synaptic connectivity on one hand, while it weakens synaptic strength by reducing synaptic AMPARs on the other hand.

\section{References}

Aiba A, Kano M, Chen C, Stanton ME, Fox GD, Herrup K, Zwingman TA, Tonegawa S (1994) Deficient cerebellar long-term depression and impaired motor learning in mGluR1 mutant mice. Cell 79:377-388.

Araki K, Meguro H, Kushiya E, Takayama C, Inoue Y, Mishina M (1993) Selective expression of the glutamate receptor channel delta 2 subunit in cerebellar Purkinje cells. Biochem Biophys Res Commun 197:1267-1276.

Araki K, Araki M, Miyazaki J, Vassalli P (1995) Site-specific recombination of a transgene in fertilized eggs by transient expression of Cre recombinase. Proc Natl Acad Sci U S A 92:160-164.

Barbour B (1993) Synaptic currents evoked in Purkinje cells by stimulating individual granule cells. Neuron 11:759-769.

Bats C, Groc L, Choquet D (2007) The interaction between Stargazin and PSD-95 regulates AMPA receptor surface trafficking. Neuron 53:719-734.

Baude A, Molnár E, Latawiec D, Mcllhinney RA, Somogyi P (1994) Synaptic and nonsynaptic localization of the GluR1 subunit of the AMPA-type excitatory amino acid receptor in the rat cerebellum. J Neurosci 14:2830-2843.

Bochet P, Audinat E, Lambolez B, Crépel F, Rossier J, Iino M, Tsuzuki K, Ozawa S (1994) Subunit composition at the single-cell level explains functional properties of a glutamate-gated channel. Neuron 12:383-388.

Bredt DS, Nicoll RA (2003) AMPA receptor trafficking at excitatory synapses. Neuron 40:361-379.

Brunel N, Hakim V, Isope P, Nadal JP, Barbour B (2004) Optimal information storage and the distribution of synaptic weights: perceptron versus Purkinje cell. Neuron 43:745-757.

Burnashev N, Khodorova A, Jonas P, Helm PJ, Wisden W, Monyer H, Seeburg PH, Sakmann B (1992) Calcium-permeable AMPA-kainate receptors in fusiform cerebellar glial cells. Science 256:1566-1570.

Ehrlich I, Malinow R (2004) Postsynaptic density 95 controls AMPA receptor incorporation during long-term potentiation and experience-driven synaptic plasticity. J Neurosci 24:916-927.

Ekerot CF, Jörntell H (2001) Parallel fibre receptive fields of Purkinje cells and interneurons are climbing fibre-specific. Eur J Neurosci 13:1303-1310.

Foster KA, Kreitzer AC, Regehr WG (2002) Interaction of postsynaptic receptor saturation with presynaptic mechanisms produces a reliable synapse. Neuron 36:1115-1126.

Fukaya M, Watanabe M (2000) Improved immunohistochemical detection of postsynaptically located PSD-95/SAP90 protein family by protease section pretreatment: a study in the adult mouse brain. J Comp Neurol 426:572-586.

Fukaya M, Ueda H, Yamauchi K, Inoue Y, Watanabe M (1999) Distinct spatiotemporal expression of mRNAs for the PSD-95/SAP90 protein family in the mouse brain. Neurosci Res 33:111-118.

Gainey MA, Hurvitz-Wolff JR, Lambo ME, Turrigiano GG (2009) Synaptic scaling requires the GluR2 subunit of the AMPA receptor. J Neurosci 29:6479-6489.

Gardner SM, Takamiya K, Xia J, Suh JG, Johnson R, Yu S, Huganir RL (2005) Calcium-permeable AMPA receptor plasticity is mediated by subunitspecific interactions with PICK1 and NSF. Neuron 45:903-915.

Guastavino JM, Sotelo C, Damez-Kinselle I (1990) Hot-foot murine muta- 
tion: behavioral effects and neuroanatomical alterations. Brain Res 523:199-210.

Hirai H, Launey T, Mikawa S, Torashima T, Yanagihara D, Kasaura T, Miyamoto A, Yuzaki M (2003) New role of delta2-glutamate receptors in AMPA receptor trafficking and cerebellar function. Nat Neurosci 6:869-876.

Hirai H, Pang Z, Bao D, Miyazaki T, Li L, Miura E, Parris J, Rong Y, Watanabe M, Yuzaki M, Morgan JI (2005) Cbln1 is essential for synaptic integrity and plasticity in the cerebellum. Nat Neurosci 8:1534-1541.

Hollmann M, Heinemann S (1994) Cloned glutamate receptors. Annu Rev Neurosci 17:31-108.

Isope P, Barbour B (2002) Properties of unitary granule cell->Purkinje cell synapses in adult rat cerebellar slices. J Neurosci 22:9668-9678.

Ito-Ishida A, Miura E, Emi K, Matsuda K, Iijima T, Kondo T, Kohda K, Watanabe M, Yuzaki M (2008) Cbln1 regulates rapid formation and maintenance of excitatory synapses in mature cerebellar Purkinje cells in vitro and in vivo. J Neurosci 28:5920-5930.

Jonas P, Racca C, Sakmann B, Seeburg PH, Monyer H (1994) Differences in $\mathrm{Ca}^{2+}$ permeability of AMPA-type glutamate receptor channels in neocortical neurons caused by differential GluR-B subunit expression. Neuron 12:1281-1289.

Kano M, Hashimoto K, Kurihara H, Watanabe M, Inoue Y, Aiba A, Tonegawa S (1997) Persistent multiple climbing fiber innervation of cerebellar Purkinje cells in mice lacking mGluR1. Neuron 18:71-79.

Kashiwabuchi N, Ikeda K, Araki K, Hirano T, Shibuki K, Takayama C, Inoue Y, Kutsuwada T, Yagi T, Kang Y, Aizawa S, Mishina M (1995) Impairment of motor coordination, Purkinje cell synapse formation, and cerebellar longterm depression in GluR delta 2 mutant mice. Cell 81:245-252.

Keinänen K, Wisden W, Sommer B, Werner P, Herb A, Verdoorn TA, Sakmann B, Seeburg PH (1990) A family of AMPA-selective glutamate receptors. Science 249:556-560.

Kitayama K, Abe M, Kakizaki T, Honma D, Natsume R, Fukaya M, Watanabe M, Miyazaki J, Mishina M, Sakimura K (2001) Purkinje cell-specific and inducible gene recombination system generated from C57BL/6 mouse ES cells. Biochem Biophys Res Commun 281:1134-1140.

Kurihara H, Hashimoto K, Kano M, Takayama C, Sakimura K, Mishina M, Inoue Y, Watanabe M (1997) Impaired parallel fiber->Purkinje cell synapse stabilization during cerebellar development of mutant mice lacking the glutamate receptor delta2 subunit. J Neurosci 17:9613-9623.

Lalouette A, Lohof A, Sotelo C, Guénet J, Mariani J (2001) Neurobiological effects of a null mutation depend on genetic context: comparison between two hotfoot alleles of the delta-2 ionotropic glutamate receptor. Neuroscience 105:443-455.

Lambolez B, Audinat E, Bochet P, Crépel F, Rossier J (1992) AMPA receptor subunits expressed by single Purkinje cells. Neuron 9:247-258.

Landsend AS, Amiry-Moghaddam M, Matsubara A, Bergersen L, Usami S, Wenthold RJ, Ottersen OP (1997) Differential localization of delta glutamate receptors in the rat cerebellum: coexpression with AMPA receptors in parallel fiber-spine synapses and absence from climbing fiber-spine synapses. J Neurosci 17:834-842.

Liu SJ, Cull-Candy SG (2002) Activity-dependent change in AMPA receptor properties in cerebellar stellate cells. J Neurosci 22:3881-3889.

Liu SQ, Cull-Candy SG (2000) Synaptic activity at calcium-permeable AMPA receptors induces a switch in receptor subtype. Nature 405:454-458.

Lomeli H, Sprengel R, Laurie DJ, Köhr G, Herb A, Seeburg PH, Wisden W (1993) The rat delta-1 and delta-2 subunits extend the excitatory amino acid receptor family. FEBS Lett 315:318-322.

Malinow R, Malenka RC (2002) AMPA receptor trafficking and synaptic plasticity. Annu Rev Neurosci 25:103-126.

Masugi-Tokita M, Tarusawa E, Watanabe M, Molnár E, Fujimoto K, Shigemoto R (2007) Number and density of AMPA receptors in individual synapses in the rat cerebellum as revealed by SDS-digested freeze-fracture replica labeling. J Neurosci 27:2135-2144.

Matsuda I, Mishina M (2000) Identification of a juxtamembrane segment of the glutamate receptor delta2 subunit required for the plasma membrane localization. Biochem Biophys Res Commun 275:565-571.

Matsuda K, Miura E, Miyazaki T, Kakegawa W, Emi K, Narumi S, Fukazawa Y, Ito-Ishida A, Kondo T, Shigemoto R, Watanabe M, Yuzaki M (2010) Cbln1 is a ligand for an orphan glutamate receptor delta2, a bidirectional synapse organizer. Science 328:363-368.

Matsuda S, Launey T, Mikawa S, Hirai H (2000) Disruption of AMPA re- ceptor GluR2 clusters following long-term depression induction in cerebellar Purkinje neurons. EMBO J 19:2765-2774.

McGee AW, Topinka JR, Hashimoto K, Petralia RS, Kakizawa S, Kauer FW, Aguilera-Moreno A, Wenthold RJ, Kano M, Bredt DS (2001) PSD-93 knock-out mice reveal that neuronal MAGUKs are not required for development or function of parallel fiber synapses in cerebellum. J Neurosci 21:3085-3091.

Mishina M, Sakimura K (2007) Conditional gene targeting on the pure C57BL/6 genetic background. Neurosci Res 58:105-112.

Miura E, Fukaya M, Sato T, Sugihara K, Asano M, Yoshioka K, Watanabe M (2006) Expression and distribution of JNK/SAPK-associated scaffold protein JSAP1 in developing and adult mouse brain. J Neurochem 97:1431-1446.

Miura E, Matsuda K, Morgan JI, Yuzaki M, Watanabe M (2009) Cbln1 accumulates and colocalizes with Cbln3 and GluRdelta2 at parallel fiberPurkinje cell synapses in the mouse cerebellum. Eur J Neurosci 29:693-706.

Miyazaki T, Fukaya M, Shimizu H, Watanabe M (2003) Subtype switching of vesicular glutamate transporters at parallel fibre-Purkinje cell synapses in developing mouse cerebellum. Eur J Neurosci 17:2563-2572.

Miyazaki T, Yamasaki M, Uchigashima M, Matsushima A, Watanabe M (2011) Cellular expression and subcellular localization of secretogranin II in the mouse hippocampus and cerebellum. Eur J Neurosci 33:82-94.

Momiyama A, Silver RA, Hausser M, Notomi T, Wu Y, Shigemoto R, CullCandy SG (2003) The density of AMPA receptors activated by a transmitter quantum at the climbing fibre-Purkinje cell synapse in immature rats. J Physiol 549:75-92.

Nagy GG, Al-Ayyan M, Andrew D, Fukaya M, Watanabe M, Todd AJ (2004) Widespread expression of the AMPA receptor GluR2 subunit at glutamatergic synapses in the rat spinal cord and phosphorylation of GluR1 in response to noxious stimulation revealed with an antigen-unmasking method. J Neurosci 24:5766-5777.

Nusser Z, Lujan R, Laube G, Roberts JD, Molnar E, Somogyi P (1998) Cell type and pathway dependence of synaptic AMPA receptor number and variability in the hippocampus. Neuron 21:545-559.

Palay S, Chan-Palay V (1974) Cerebellar cortex: cytology and organization, pp 63-69, 242-287. New York: Springer.

Pellegrini-Giampietro DE, Bennett MV, Zukin RS (1991) Differential expression of three glutamate receptor genes in developing rat brain: an in situ hybridization study. Proc Natl Acad Sci U S A 88:4157-4161.

Petralia RS, Wang YX, Mayat E, Wenthold RJ (1997) Glutamate receptor subunit 2-selective antibody shows a differential distribution of calciumimpermeable AMPA receptors among populations of neurons. J Comp Neurol 385:456-476.

Pozo K, Goda Y (2010) Unraveling mechanisms of homeostatic synaptic plasticity. Neuron 66:337-351.

Roche KW, Ly CD, Petralia RS, Wang YX, McGee AW, Bredt DS, Wenthold RJ (1999) Postsynaptic density-93 interacts with the delta2 glutamate receptor subunit at parallel fiber synapses. J Neurosci 19:3926-3934.

Sato K, Kiyama H, Tohyama M (1993) The differential expression patterns of messenger RNAs encoding non- $N$-methyl-D-aspartate glutamate receptor subunits (GluR1-4) in the rat brain. Neuroscience 52:515-539.

Schnell E, Sizemore M, Karimzadegan S, Chen L, Bredt DS, Nicoll RA (2002) Direct interactions between PSD-95 and stargazin control synaptic AMPA receptor number. Proc Natl Acad Sci U S A 99:13902-13907.

Shepherd JD, Huganir RL (2007) The cell biology of synaptic plasticity: AMPA receptor trafficking. Annu Rev Cell Dev Biol 23:613-643.

Shi S, Hayashi Y, Esteban JA, Malinow R (2001) Subunit-specific rules governing AMPA receptor trafficking to synapses in hippocampal pyramidal neurons. Cell 105:331-343.

Slot JW, Geuze HJ (1985) A new method of preparing gold probes for multiple-labeling cytochemistry. Eur J Cell Biol 38:87-93.

Stein V, House DR, Bredt DS, Nicoll RA (2003) Postsynaptic density-95 mimics and occludes hippocampal long-term potentiation and enhances long-term depression. J Neurosci 23:5503-5506.

Takayama C, Nakagawa S, Watanabe M, Mishina M, Inoue Y (1996) Developmental changes in expression and distribution of the glutamate receptor channel delta 2 subunit according to the Purkinje cell maturation. Brain Res Dev Brain Res 92:147-155.

Takeuchi T, Nomura T, Tsujita M, Suzuki M, Fuse T, Mori H, Mishina M (2002) Flp recombinase transgenic mice of C57BL/6 strain for conditional gene targeting. Biochem Biophys Res Commun 293:953-957. 
Takeuchi T, Miyazaki T, Watanabe M, Mori H, Sakimura K, Mishina M (2005) Control of synaptic connection by glutamate receptor delta2 in the adult cerebellum. J Neurosci 25:2146-2156.

Tanaka J, Nakagawa S, Kushiya E, Yamasaki M, Fukaya M, Iwanaga T, Simon MI, Sakimura K, Kano M, Watanabe M (2000) Gq protein alpha subunits Galphaq and Galpha11 are localized at postsynaptic extra-junctional membrane of cerebellar Purkinje cells and hippocampal pyramidal cells. Eur J Neurosci 12:781-792.

Tempia F, Kano M, Schneggenburger R, Schirra C, Garaschuk O, Plant T, Konnerth A (1996) Fractional calcium current through neuronal AMPAreceptor channels with a low calcium permeability. J Neurosci 16:456-466.

Tsujita M, Mori H, Watanabe M, Suzuki M, Miyazaki J, Mishina M (1999) Cerebellar granule cell-specific and inducible expression of Cre recombinase in the mouse. J Neurosci 19:10318-10323.

Uemura T, Mori H, Mishina M (2004) Direct interaction of GluRdelta2 with Shank scaffold proteins in cerebellar Purkinje cells. Mol Cell Neurosci 26:330-341.

Uemura T, Kakizawa S, Yamasaki M, Sakimura K, Watanabe M, Iino M, Mishina M (2007) Regulation of long-term depression and climbing fiber territory by glutamate receptor delta2 at parallel fiber synapses through its C-terminal domain in cerebellar Purkinje cells. J Neurosci $27: 12096-12108$
Uemura T, Lee SJ, Yasumura M, Takeuchi T, Yoshida T, Ra M, Taguchi R, Sakimura K, Mishina M (2010) Trans-synaptic interaction of GluRdelta2 and Neurexin through Cbln1 mediates synapse formation in the cerebellum. Cell 141:1068-1079.

Wang YT, Linden DJ (2000) Expression of cerebellar long-term depression requires postsynaptic clathrin-mediated endocytosis. Neuron 25:635-647.

Yamasaki M, Matsui M, Watanabe M (2010) Preferential localization of muscarinic M1 receptor on dendritic shaft and spine of cortical pyramidal cells and its anatomical evidence for volume transmission. J Neurosci 30: $4408-4418$.

Yamazaki M, Fukaya M, Hashimoto K, Yamasaki M, Tsujita M, Itakura M, Abe M, Natsume R, Takahashi M, Kano M, Sakimura K, Watanabe M (2010) TARPs gamma-2 and gamma-7 are essential for AMPA receptor expression in the cerebellum. Eur J Neurosci 31:2204-2220.

Yoshida T, Katoh A, Ohtsuki G, Mishina M, Hirano T (2004) Oscillating Purkinje neuron activity causing involuntary eye movement in a mutant mouse deficient in the glutamate receptor delta2 subunit. J Neurosci 24:2440-2448.

Yuzaki M (2009) New (but old) molecules regulating synapse integrity and plasticity: Cbln1 and the delta2 glutamate receptor. Neuroscience 162: 633-643. 